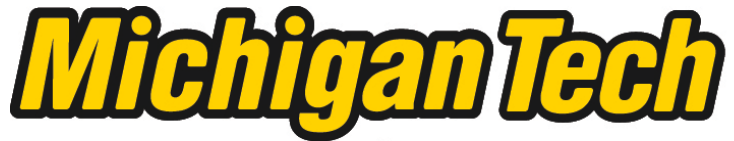 \\ Michigan Technological University Create the Future Digital Commons @ Michigan Tech
}

\section{Influence of Vegetation Removal and Altering Water Levels on CO2 Flux Rates of a Northern Bog}

Laura M. Matkala

Michigan Technological University

Follow this and additional works at: https://digitalcommons.mtu.edu/etds

Part of the Ecology and Evolutionary Biology Commons

Copyright 2013 Laura M. Matkala

\section{Recommended Citation}

Matkala, Laura M., "Influence of Vegetation Removal and Altering Water Levels on CO2 Flux Rates of a Northern Bog", Master's Thesis, Michigan Technological University, 2013.

https://doi.org/10.37099/mtu.dc.etds/597

Follow this and additional works at: https://digitalcommons.mtu.edu/etds

Part of the Ecology and Evolutionary Biology Commons 
INFLUENCE OF VEGETATION REMOVAL AND ALTERING WATER LEVELS $\mathrm{ON} \mathrm{CO}_{2}$ FLUX RATES OF A NORTHERN BOG

\author{
By \\ Laura M. Matkala

\begin{abstract}
A THESIS
Submitted in partial fulfillment of the requirements for the degree of MASTER OF SCIENCE

In Applied Ecology
\end{abstract} \\ MICHIGAN TECHNOLOGICAL UNIVERSITY \\ 2013 \\ (C) 2013 Laura M. Matkala
}


This thesis has been approved in partial fulfillment of the requirements for the Degree of MASTER OF SCIENCE in Applied Ecology.

School of Forest Resources and Environmental Science

Thesis Co-Advisor: Rodney A. Chimner

Thesis Co-Advisor: Harri Vasander

Committee Member: Thomas G. Pypker

Committee Member: Casey J. Huckins

School Dean: Terry L. Sharik 


\section{Table of Contents}

INFLUENCE OF VEGETATION REMOVAL AND ALTERING WATER LEVELS

$\mathrm{ON} \mathrm{CO}_{2}$ FLUX RATES OF A NORTHERN BOG................................1

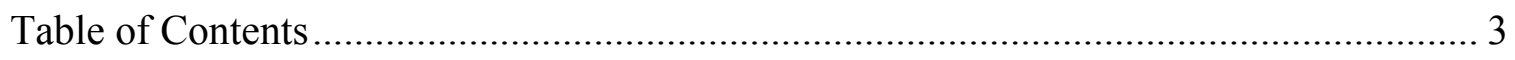

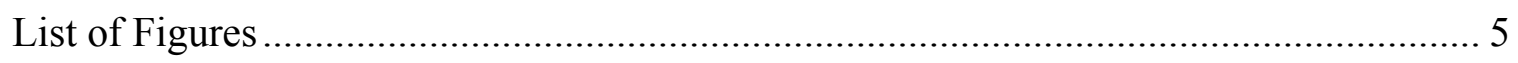



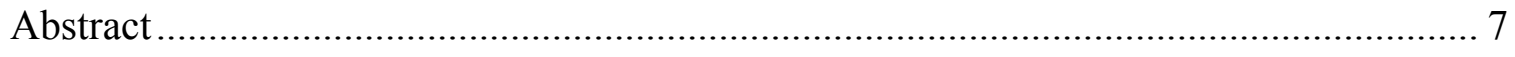



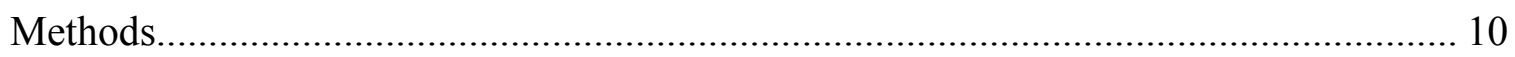

Site Description and Experimental Design ............................................................... 10

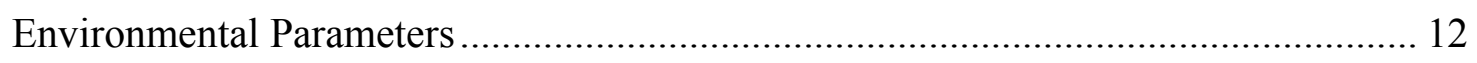

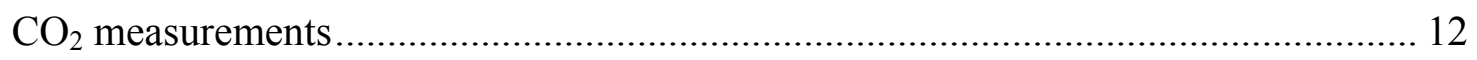

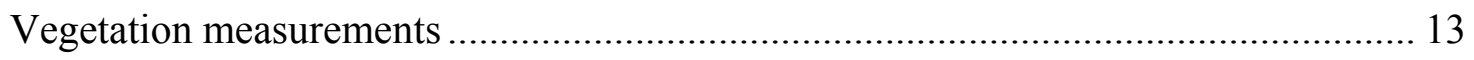

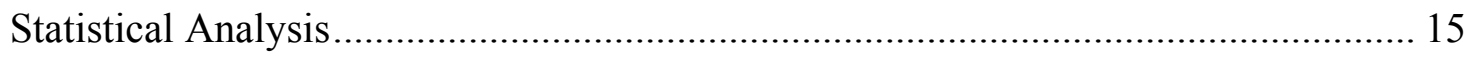

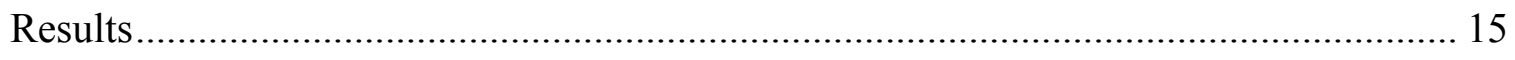

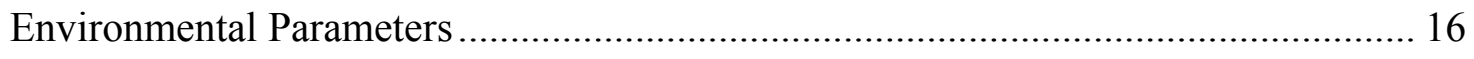

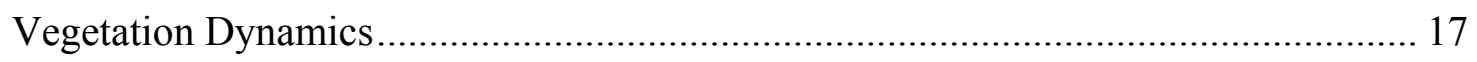

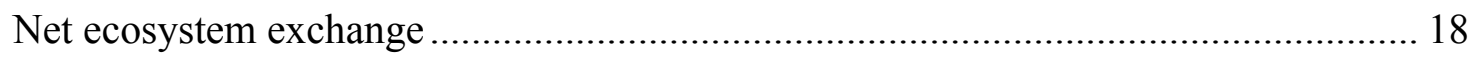

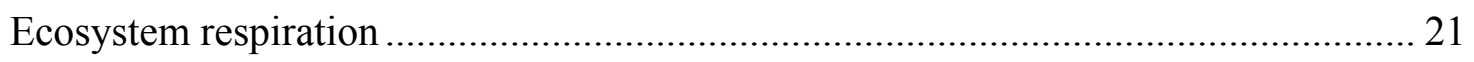

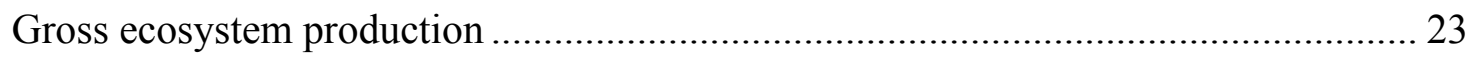

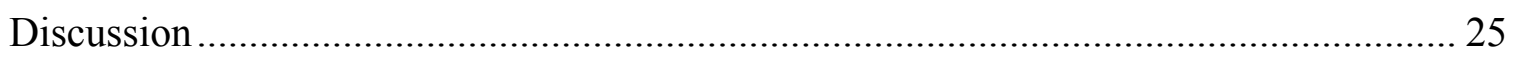

Differences in NEE, ER and GEP between treatments and over time.......................... 25

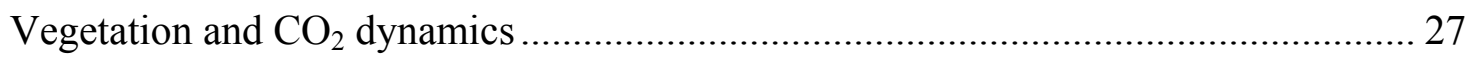


Environmental parameters and NEE, ER and GEP

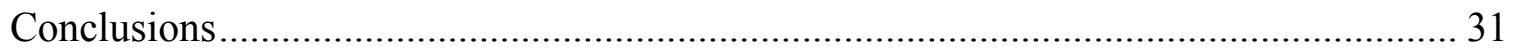

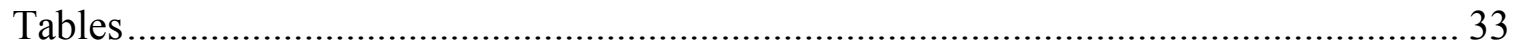

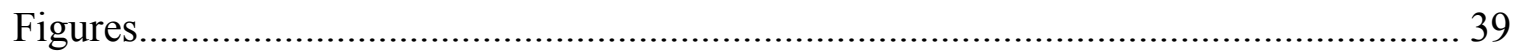

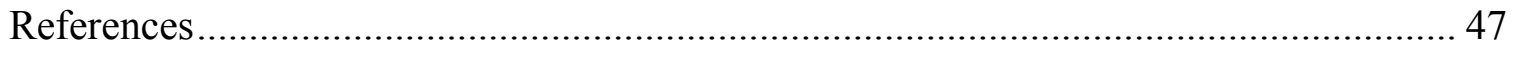




\section{List of Figures}

Figure 1. Water levels and treatment combinations in 2010 (a.), 2011(b.) and 2012 (c.).

Figure 2. Peat temperatures of different treatments in different depths $(5-80 \mathrm{~cm}$ below

surface)....... 40

Figure 3. Different treatments and their mean NEE, ER and GEP rates in 2012.

Figure 4. Different treatments and their NEE, ER and GEP rates means of 2012 July, August and September

Figure 5. The mean NEE, ER and GEP of the control plots in 2011 after starting the treatments and 2012.

Figure 6. NEE of different water level and vegetation treatment combinations on sampling days of 2010 (a.), 2011 (b.) and 2012 (c.).

Figure 7. ER of different water level and vegetation treatment combinations on sampling days of 2010 (a.), 2011 (b.) and 2012 (c.). 45

Figure 8. GEP of different water level and vegetation treatment combinations on sampling days of 2010 (a.), 2011 (b.) and 2012 (c.). 46 


\section{List of Tables}

Table 1.The correlations between air temperature and peat temperatures on different

depths below surface $(5,10,20,40$ and $80 \mathrm{~cm})$ by treatment in 2011 and 2012.

Table 2. Mean percentage cover of plant species on different treatments in 2010-2012. 34

Table 3. Aboveground biomass (g/m2) living/senesced plants for different plots in 2012 .

Table 4. The correlations of $\mathrm{CO}_{2}$ flux of the control plots and air temperature and water level for 2011 after starting the treatments and 2012.

Table 5. Within-subjects effects of the repeated measures analysis.

Table 6. Between-subject effects of the repeated measures analysis. 38 


\section{Abstract}

Boreal peatlands contain approximately one third of the global soil carbon and are considered net sinks of atmospheric $\mathrm{CO}_{2}$. Water level position is one of the main regulators of $\mathrm{CO}_{2}$ fluxes in northern peatlands because it controls both the thickness of the aerobic layer in peat and plant communities. However, little is known about the role of different plant functional groups and their possible interaction with changing water level in boreal peatlands with regard to $\mathrm{CO}_{2}$ cycling. Climate change may also accelerate changes in hydrological conditions, changing both aerobic conditions and plant communities. To help answer these questions, this study was conducted at a mesocosm facility in Northern Michigan where the aim was to experimentally study the effects of water levels, plant functional groups (sedges, shrubs and mosses) and the possible interaction of these on the $\mathrm{CO}_{2}$ cycle of a boreal peatland ecosystem.

The results indicate that Ericaceous shrubs are important in the boreal peatland $\mathrm{CO}_{2}$ cycle. The removal of these plants decreased ecosystem respiration, gross ecosystem production and net ecosystem exchange rates, whereas removing sedges did not show any significant differences in the flux rates. The water level did not significantly affect the flux rates. The amount of aboveground sedge biomass was higher in the low water level sedge treatment plots compared to the high water level sedge plots, possibly because the lowered water level and the removal of Ericaceae released nutrients for sedges to use up.

Key words: peatland, $\mathrm{CO}_{2}$ flux, sedge, shrub, water level 


\section{Introduction}

Peatlands store an estimated one third of the Earth's soil organic carbon (Moore et al. 1998), which is more than half of the amount of carbon in the atmosphere (Gorham 1991). The carbon stocks of peatlands are large because over the long-term plant production is greater than the loss of carbon from decomposition, fires, and dissolved organic carbon (Brown 1998; Moore et al. 1998). Peatlands are, therefore, long-term net sinks for atmospheric $\mathrm{CO}_{2}$ (Moore et al. 1998; Dorrepaal et al. 2009), which is a greenhouse gas in the atmosphere (Wuebbles and Hayhoe 2002).

Plants take up $\mathrm{CO}_{2}$ during photosynthesis and release it during respiration (Lambers et al. 2008), which occurs both in aboveground and belowground parts of the plants. The belowground respiration occurs in the roots and rhizosphere (Le Mer and Rogers 2001), which are in the anaerobic peat layer, or catotelm (Brown 1998). Carbon dioxide is produced also when plant biomass decomposes. Most decomposition occurs in the acrotelm, or the uppermost aerobic layer of peat (Brown 1998).

Changing climate has been predicted to increase precipitation in the northern boreal and temperate areas (Lemke et al. 2007) where most of the peatlands are located (Rydin and Jeglum 2006). In the northernmost regions this, together with the predicted rise in the air temperature (Trenberth et al. 2007), could cause thawing of permafrost peatlands (Frolking et al. 2011). Permafrost thawing is patchy and results in thermokarst terrain with an uneven surface topography (Lemke et al. 2007). This has been reported to raise the water tables in arctic areas (Hinzman et al. 2005; Oksanen and Väliranta 2006). On the other hand the rising temperatures further south may lead to higher evapotranspiration rates and lower the water table levels of peatlands (Gorham 1991; Frolking et al. 2011).

The position of the water table is an important regulator of peatland $\mathrm{CO}_{2}$ cycling (Davidson and Janssens 2006). Peatlands with low water levels tend to have 
higher $\mathrm{CO}_{2}$ emissions peatlands with high water level, because their aerobic peat layer is thicker (Moore and Knowles 1989; Silvola et al. 1996; Goulden and Crill 1997; Komulainen et al. 1999; Whalen 2005; Chivers et al. 2009). Decreasing water levels could stimulate aerobic heterotrophic respiration so that ecosystem respiration exceeds photosynthesis rates, making peatlands a source of $\mathrm{CO}_{2}$ (Moore et al. 1998; Davidson and Janssens 2006). Lower water levels may also lead to higher photosynthesis rates and plant growth through increased soil temperature and oxygen supply to plant roots, as well as higher availability of nutrients (Shaver et al. 1992). In order for photosynthesis rates in a peatland to increase more than decomposition rates in warmer and drier conditions, increased nutrient mineralization is usually required because most northern peatlands are nutrient limited (Shaver et al. 1992).

Changes in water table levels can also cause changes in vegetation communities (Lemke et al. 2007). For instance, several studies, including peatland restoration studies, have shown that increasing water levels can change plant communities (Moore and Knowles 1989; Komulainen et al. 1999). Drier conditions can also change peatland communities, such as from a sedge-dominated to shrub-dominated on a relatively short time-scale (Bubier et al. 2003).

Different plant species have different structures and photosynthesis rates (e.g. Lambers et al. 2008), so the net exchange, respiration and gross production rates of an ecosystem can change with changes in plant communities. For instance, woody plant tissue has a carbon: nitrogen $(\mathrm{C}: \mathrm{N})$ ratio of approximately 200:1, whereas herbaceous plant tissue $\mathrm{C}: \mathrm{N}$ ratio is about 100:1. This ratio describes how efficiently a plant can use available nitrogen in order to store carbon (Shaver et al. 1992). Ericaceae-dominated bogs have, however, lower photosynthesis rates relative to respiration than sedgedominated fens, which means that sedge-dominated fens have the potential to sequester more $\mathrm{CO}_{2}$ (Bellisario et al. 1998). Sedges can tolerate waterlogged conditions better than shrubs because of their aerenchyma cells but they are not drought tolerant like shrubs (Bubier et al. 2003). However, in the absence of shrubs, sedge production was found to 
increase when water tables decreased (Strack et al. 2006). This was explained by the ability of sedges to acquire deep water as their roots were found to extend deeper in the dry peat (Strack et al. 2006). Woody plants have higher rates of $\mathrm{CO}_{2}$ exchange in drier conditions compared to wet conditions, whereas for sedges only respiration rates increased in dry conditions (Bubier et al. 2003). Peatlands rich in woody plant vegetation might be able to balance out the loss of $\mathrm{CO}_{2}$ through increased respiration caused by lowered water table and warmer temperature (Bubier et al. 2003).

Despite their abundance, information of the role of Ericaceae in the $\mathrm{CO}_{2}$ cycle of northern peatland ecosystems is still scarce. Many of the sedge and moss related peatland studies have also concentrated more on the methane $\left(\mathrm{CH}_{4}\right)$ cycle, (e.g. (Bubier 1995; Waddington et al. 1996; Raghoebarsing et al. 2005; Treat et al. 2007; Larmola et al. 2010), rather than the $\mathrm{CO}_{2}$ cycle. Yet, these plant groups are very abundant on boreal peatlands (e.g.Roulet et al. 1992; Shannon and White 1994; Bellisario et al. 1998; Bubier et al. 2003), which may be facing hydrological changes caused by the climate change (Frolking et al. 2011; Lemke et al. 2007). Therefore, the objective of this study was to experimentally test how ecosystem $\mathrm{CO}_{2}$ cycling is influenced in peatlands by the interactive effects of: 1) changing water table levels, and 2) different plant functional groups (moss, sedge and Ericaceae).

\section{Methods}

\section{Site Description and Experimental Design}

The study was conducted at a mesocosm facility (PEATCOSM) at the US Forest Service, Northern Research Station in Houghton ( $\left.47^{\circ} 7^{\prime} 2^{\prime \prime} \mathrm{N} 88^{\circ} 33^{\prime} 45^{\prime \prime} \mathrm{W}\right)$, Michigan. The facility consists of $241 \mathrm{~m}$ x $1 \mathrm{~m}$ x $1 \mathrm{~m}$ teflon coated stainless steel bins of intact peat. The bins are open from above with a tunnel below the bins that has a controlled climate and access to and below-ground visibility of the bins. 
The peat cubes were collected from a bog site near Meadowlands, Minnesota and transferred to Houghton in May 2010. Once in Houghton, each bin was individually monitored and water table levels controlled by either removing or adding water (Potvin et al. unpublished data). In the beginning of the field season 2011 minirhizotron tubes, environmental sensors and the water control system were installed. The first $\mathrm{CO}_{2}$ gas exchange measurements were performed once a month in July, August and September 2010 and the first full field season of $\mathrm{CO}_{2}$ measurements started in May 2011. The experimental plant treatments were established in June 2011. The plant treatments consisted of 1) Ericaceae (shrubs) were removed from one third of the bins, 2) Carex (sedges) from one third of the bins and 3) the remaining eight bins were left as control plots. The plants were removed by gently pulling them up with their roots. The bins were checked every week to see if additional plant removal was necessary. In addition to the plant treatment, we also established two water table treatments: 1) high water and 2) low water. Long-term precipitation and water table depth data from Marcell Experimental Forest was used to determine the high and low water levels. The high water level is imitating a high minimum water table year with a typical low variability in water table depth over the season. The low water level imitates a low minimum water table year with a high variability in water table depth over the season. This design gave us 6 treatments: 1) high water level with sedges removed (HE), 2) high water level with Ericaceae removed (HS), 3) low water level with sedges removed (LE), 4) low water level with Ericaceae removed (LS), and 5) control plots with high water level (HC) and 6) control plots with low water level (LC).

Problems occurred after the vegetation removal, as the mosses started drying out and dying in the bins from which Ericaceae had been removed. Therefore, the water levels had to be raised in order to keep the vegetation alive, so the data from year 2011 is not consistent when it comes to water levels. However, in the field season of 2012 the water levels were successfully set to high and low. Additions of artificial 
rainwater were used to increase the water tables and rainout shelters were employed during rain events to exceed water from bins where water tables would have become too high. If water tables needed to be lowered water was removed from the bins through drainage ports set $10-15 \mathrm{~cm}$ below the peat surface.

\section{Environmental Parameters}

Peat temperature sensors (Temperature Probes 107, Campbell Scientific Inc., Logan, UT, USA) were installed in winter 2011. The temperature is monitored at five different depths in each bin: $5 \mathrm{~cm}, 10 \mathrm{~cm}, 20 \mathrm{~cm}, 40 \mathrm{~cm}$ and $80 \mathrm{~cm}$, and at 2 locations (one in the center and one $10 \mathrm{~cm}$ away from the edge of the bin) and recorded hourly. Air temperature (HMP50-L, Vaisala Oyj, Finland) is measured hourly at four locations, one by bins number 6 and 14 and two by bin 18 . There are also similar sensors in the fence surrounding the mesocosms, on the top, in the middle and on the bottom. Daily rainfall has been measured (385-L, Met One Instruments, Inc., Grants Pass, OR, USA) since early 2011 and wind speed (2 D Windsonic-4 L, Gill Instruments Ltd., Lymington, Hampshire, UK) and PAR (photosynthetically active radiation) since late 2010 (LI 190s B-L Quantum Sensor, LI-COR Biosciences, Lincoln, NE, USA) at the meteorological station. The water level measurements started in 2010 but the data for the first sampling dates in May in 2011 is missing. The water levels are measured hourly and recorded with a CR 1000 Datalogger (Campbell Scientific Inc., Logan, UT, USA). Daily means from temperature and water level parameters were used in the calculations.

$\mathrm{CO}_{2}$ measurements 
$\mathrm{CO}_{2}$ fluxes were measured from each bin approximately once a week during the summer and biweekly in the fall of 2011 and in 2012. Monthly measurements were conducted in 2010 when the experiment was being set up. Carbon dioxide flux rates were measured using a custom built clear PVC chamber $(100 \mathrm{~cm} \times 100 \mathrm{~cm} \times 40 \mathrm{~cm})$ with small fans in conjunction with an EGM-4 Environmental Gas Monitor (PP-Systems, Amesbury, MA, USA). Clear chamber techniques have been used previously in several studies to measure $\mathrm{CO}_{2}$ exchange (Vourlitis et al. 1993; Chivers et al. 2009; Chimner et al. 2010). Photosynthetically Active Radiation (PAR) was measured simultaneously by using the standard EGM-4 TRP-1 probe inserted into the clear chamber. The lid was put on for each measurement and taken off between them to let the air inside the chamber mix with the ambient air (Vourlitis et al. 1993). Each measurement was running for 120 seconds with the EGM-4 logging the results from measuring the difference between the $\mathrm{CO}_{2}$ concentration of the air going in and the air coming out. Directly after doing a light measurement for net ecosystem exchange (NEE), which is the net exchange of $\mathrm{CO}_{2}$ between an ecosystem and the atmosphere (Wofsy et al. 1993), a dark measurement for ecosystem respiration (ER) was conducted for every bin by using a non-transparent dark cloth that was put on the chamber (Vourlitis et al. 1993). Ecosystem respiration is plant and soil respiration together (Moore et al. 1998). The sampling was performed similarly as the NEE measurement. Gross ecosystem production (GEP), which is the total amount of $\mathrm{CO}_{2}$ assimilated by an ecosystem (Wofsy et al. 1993), was calculated by subtracting ER from NEE. In this study ER is referred to with negative numbers and NEE and GEP with positive numbers. The unit used for $\mathrm{CO}_{2}$ flux rates is $\mu \mathrm{mol} \mathrm{m} \mathrm{m}^{-2}$. The values, where $\mathrm{R}^{2}$ between the $\mathrm{CO}_{2}$ concentration (ppm) and time was lower than 0.8 , were excluded from the calculations.

\section{Vegetation measurements}


A vegetation survey for each bin was conducted annually in the late summer by using a point intercept method. A one meter tall metal frame structure with 8 $\mathrm{x} 8$ grid was set on top of a bin. A removable beam with 8 holes drilled in it, $10 \mathrm{~cm}$ away from each other, was used so that there were 64 holes and data points altogether. Laser pens were put in each hole of the frame. Each species as well as the plant organ (dead or alive) the laser touched and how many hits the laser caught in each data point were recorded. The percentage cover of each species was calculated based on these surveys (Potvin et al. unpublished).

The ground layer of the original vegetation in the bins consists mostly of Sphagnum species: S. rubellum, S.magellanicum and S. fuscum with some Polytrichum strictum. Vaccinium oxycoccos is also present in the ground layer. The field layer is composed of Chamaedaphne calyculata, Carex oligosperma, Kalmia polifolia, and some Ledum groenlandicum and Andromeda glaucophylla.

The aboveground biomass calculation was done based on the three most abundant species of the field layer: C. calyculata, C. oligosperma and K. polifolia. Aboveground biomass of the bins was measured and calculated in 2012. Each bin was divided in six sections with fiber glass rods that were taped into the foam edges of the bin. Digital calipers were used to measure the diameter of the main stem of each $K$. polifolia and C. calyculata. This was done separately for each section. Aboveground biomass was calculated by using the diameters in an allometric equation that was developed at the original site in Meadowlands (Potvin et al. unpublished data). The aboveground biomass of $C$. oligosperma was determined by counting the number of living and dead stems and using an allometric equation developed at Nestoria, Michigan (Potvin et al. unpublished data). 


\section{Statistical Analysis}

The statistical analysis was performed by using SPSS Statistics 20 (IBM SPSS, 2011). Repeated measures analysis by year with water level (high or low) and vegetation treatment as independent, between measures, variables was performed for all NEE, ER and GEP. Bonferroni post hoc analysis was used for pairwise comparison if statistically significant differences were found between different factors. Separate repeated measures analyses were conducted for different vegetation treatments if statistically significant differences were found in the between-measures effects or if significant interactions between different main effects were detected. Stepwise multiple regression with air temperature, water level ( $\mathrm{cm}$ below peat surface) and peat temperatures as independent variables were used to see if there are interrelationships between the environmental parameters and NEE, ER and GEP values. Regressions were run for each six treatment combinations separately for years 2011 and 2012. Pearson correlations were used in the tests to see if the environmental parameters correlated with each other. One-way ANOVAs were run to see if the NEE, ER and GEP were similar from all the bins in 2010 and 2011 before the treatments. Two-way ANOVAs with water level and vegetation treatment as independent variables were performed for 2012 NEE, ER and GEP data to compare the means of different treatments. Tukey's post hoc test was used for pairwise comparisons in case statistically significant differences were found between independent variables. Simple linear regressions were also done to see how the control plot $\mathrm{CO}_{2}$ fluxes correlated with air temperature and water level (cm below surface) in 2011 after starting the treatments and 2012.

\section{Results}




\section{Environmental Parameters}

The mean daily air temperatures of the days when $\mathrm{CO}_{2}$ was measured were slightly lower in $2011\left(16.7 \pm 1.4^{\circ} \mathrm{C}\right)$ than in $2012\left(17.7 \pm 1.6^{\circ} \mathrm{C}\right)$ (mean \pm standard error). Between the first and the last measurement day of field seasons 2011 and 2012 there were 55 and 50 days with rainfall, respectively. The sum of rainfall during this time was $146 \mathrm{~mm}$ in 2011 and $151.9 \mathrm{~mm}$ in 2012. Four of the sampling days in 2011 received rainfall, two sampling days in 2012. In all rainy days except for the first one in 2011(15.7 $\mathrm{mm}$ ) rainfall was small, between approximately 0.9 and $1.4 \mathrm{~mm}$ per day. The average wind speed in the sampling days was $1.08 \pm 0.10 \mathrm{~m} / \mathrm{s}$ in 2011 and $1.03 \pm 0.05 \mathrm{~m} / \mathrm{s}$ in 2012. Averaged PAR rate in 2011 sampling days was $1622 \pm 60.8 \mu \mathrm{mol} \mathrm{m}^{-2} \mathrm{~s}^{-1}$ and 1658 $\pm 78.0 \mu \mathrm{mol} \mathrm{m}^{-2} \mathrm{~s}^{-1}$ in 2012 .

The average water table (average of the sampling dates) for high water level and low water level bins were at approximately $21.9 \pm 6.0$ and $19.3 \pm 3.4 \mathrm{~cm}$ below surface, respectively, in 2010 when the treatments were not started yet. In 2011 high water level bins had the water level on average $9.5 \pm 0.64 \mathrm{~cm}$ below surface and low water level bins $11.4 \pm 0.95 \mathrm{~cm}$ below surface. In 2012 the two different water levels were more clearly differentiated from each other (Figure 1). The high water level bins had a water table approximately $8.4 \pm 1.0 \mathrm{~cm}$ below surface and low water level bins $15.0 \pm 1.0$ $\mathrm{cm}$ below surface. A more detailed look at the water level data from 2012 shows the water table in high water level bins varied between $2.4 \mathrm{~cm}$ and $15.0 \mathrm{~cm}$ below surface and between 6.5 and $29.7 \mathrm{~cm}$ below surface in low water level bins. The water tables were at their lowest between July and October in both the high and low water level bins. The data for 2011 shows clearly the point in the beginning of August when the water levels were elevated in order to improve the condition of the mosses in the bins.

The differences in average peat temperature between treatments were small (Figure 2). In 2012, the peat temperatures at 80 and $10 \mathrm{~cm}$ below surface, respectively, 
were on average the coldest ones. Peat was warmest at $20 \mathrm{~cm}$ below surface for other treatments except for high water level sedge treatment where the peat at $40 \mathrm{~cm}$ below surface was slightly warmer. The temperature difference between the three warmest depths (20, 40 and $5 \mathrm{~cm}$ below surface) was, however, very small for all the treatments. In 2011 the peat temperatures were consistently warmer in the upper peat layer and cooled down towards the deeper layers.

Stepwise multiple regressions showed that in all the treatment combinations air temperature correlated with peat temperatures $(\mathrm{p} \leq 0.05$, Table 1$)$.

\section{Vegetation Dynamics}

Vegetation was similar in 2010 before the treatments were started (Table 2). The survey of 2011 was conducted after starting the treatments, but there were still some shrubs left in the sedge bins and some sedges in the Ericaceae bins on that year. In 2010 the average overall sedge coverage in the bins was 33\%, shrub coverage was $172 \%$ and moss coverage was $118 \%$. In 2012 the sedge coverage in the control bins had dropped by to $21 \%$ (58\% decrease). The shrub and moss coverage in the control bins in 2012 were $98 \%$ (43\% decrease) and $117 \%$ (no change), respectively. Although the overall moss coverage of the control plots did not change, species composition did change. S. rubellum continued to be the most dominant moss species in 2012 and its coverage increased by 8 $\%$ from 2010 . The coverage of $S$. fuscum increased by $6 \%$, and the coverage of $S$. magellanicum by $33 \%$, whereas the coverage of $P$. strictum decreased by $99 \%$ compared to 2010.All the shrubs in the control plots decreased between 2010 and 2012, C.calyculata by $41 \%$, K. polifolia by $49 \%$ and $V$. oxycoccos by $100 \%$. In 2012 the coverage of $C$. oligosperma in sedge plots had decreased by $78 \%$ compared to 2010 control plots. All the mosses in the sedge plots increased their coverage from 2010. P.strictum covered $38 \%$ more, S. fuscum $15 \%$ more, S. magellanicum $0.15 \%$ more and 
S. rubellum $10 \%$ more of the area in sedge plots in 2012 than in the control plots in 2010. Removing sedges decreased the area covered by P.strictum in 2012 by $61 \%$ compared to 2010 control plots. All the Sphagnum species increased their coverage in Ericaceae treatment bins, especially $S$. magellanicum with almost $40 \%$ and $S$. fuscum with approximately $30 \%$ compared to pre-treatment situation. The shrub coverage decreased in Ericaceae treatment plots compared to the pre-treatment situation. The biggest change occurred with $V$. oxycoccos, whose coverage was $64 \%$ lower in 2012 compared to 2010. C.calyculata coverage decreased by $6 \%$ and K. polifolia by $55 \%$, when comparing 2012 to pre-treatment situation. L. groenlandicum decreased by over $300 \%$, but its coverage stayed under $1 \%$ both in 2012 and 2010 .

The aboveground biomass of living and senesced plants varied between vegetation treatments (Table 3). Some of the sedge treatment bins had more dead than living sedge biomass in them, which was not observed for the control bins. There was also variation between different bins within each vegetation treatments. For example the sedge total biomasses (living + dead) in sedge treatment plots ranged between 0.5 and $33.2 \mathrm{~g} / \mathrm{m}^{2}$. The low water level sedge treatment plots had a larger total sedge biomass than the high water level plots (163.3 and $96.9 \mathrm{~g} / \mathrm{m}^{2}$, respectively) and the same occurred with high water level versus low water level total sedge biomass in control bins (52.3 and $68.7 \mathrm{~g} / \mathrm{m}^{2}$, respectively). No senesced Ericaceae were found in the bins. The Ericaceae biomass in high water level Ericaceae/shrub treatment plots was $501.3 \mathrm{~g} / \mathrm{m}^{2}$ and in low water level Ericaceae plots $513.7 \mathrm{~g} / \mathrm{m}^{2}$. In high water level control plots the Ericaceae biomass was $493.2 \mathrm{~g} / \mathrm{m}^{2}$ and in low water level control plots $449.1 \mathrm{~g} / \mathrm{m}^{2}$.

\section{Net ecosystem exchange}

The NEE results from each sampling day within each year can be seen in Figure 6 . There were only three sampling days in the year 2010. The effect of the 
vegetation removal can clearly be seen in the 2011 graph as the drop of the NEE from sedge plots in the end of June. In 2012 these plots still have lower NEE than the others do.

The mean NEE rates for all the plots for years 2010 and 2011 before the treatments were started were $5.29 \pm 0.13$ and $4.55 \pm 0.35 \mu \mathrm{mol} \mathrm{m}^{-2} \mathrm{~s}^{-1}$, respectively. The one-way ANOVA for control bins in 2010 and 2011 pre-treatments confirmed that the NEE rates between the plots were not significantly different before starting the treatments ( $p=0.566$ in 2010, $p=0.810$ in early 2011). The mean NEE rates for control bins in 2011 after starting the treatments were $6.54 \pm 1.11 \mu \mathrm{mol} \mathrm{m}^{-2} \mathrm{~s}^{-1}$ for high water level and $6.06 \pm$ $1.22 \mu \mathrm{mol} \mathrm{m}^{-2} \mathrm{~s}^{-1}$ for low water level. There was no significant difference $(\mathrm{p}>0.05)$ in 2012 between the control high and low water level treatments $\left(6.63 \pm 1.27 \mu \mathrm{mol} \mathrm{m}^{-2} \mathrm{~s}^{-1}\right.$ and $6.09 \pm 0.80 \mu \mathrm{mol} \mathrm{m}^{-2} \mathrm{~s}^{-1}$, respectively) (Figure 3 and 4).

There were significant differences in NEE between vegetation treatments in 2012 (Figure 3 and 4$)(p<0.001)$. The sedge treatment differed significantly from Ericaceae treatment (mean difference $-2.00 \mu \mathrm{mol} \mathrm{m}^{-2} \mathrm{~s}^{-1}, \mathrm{p}=0.002$ ) and control plots (mean difference $-2.50 \mu \mathrm{mol} \mathrm{m}^{-2} \mathrm{~s}^{-1}, \mathrm{p}<0.001$ ) in 2012. The NEE rates of sedge plots were lower than NEE rates of shrub and control plots (by $34 \%$ and $39 \%$, respectively). The NEE rates were $12 \%$ lower in the high water level sedge treatment compared to low water level sedge treatment. The NEE rates of high water level sedge treatment were also $45 \%$ lower compared to NEE rates of high water level control plots. The low water level sedge plots had NEE rates $33 \%$ lower than low water level control plots. The NEE of Ericaceae plots were about $8 \%$ smaller compared to control plots. The high water level Ericaceae plots had $13 \%$ higher NEE rates than low water level Ericaceae plots and $6 \%$ lower NEE rates compared to high water level control plots. The NEE rates for low water level Ericaceae treatment were $10 \%$ smaller in comparison with low water level control plots. The high water level control plot NEE rates were about $9 \%$ higher than low water level control plot NEE rates. 
The mean NEE rates from control plots on different water levels from the late season of 2011 and 2012 were similar (Figure 5). In both years the high water level showed slightly greater NEE rates than low water level, but the differences were relatively small and not significant. Simple regression analysis were also performed to the control plots to see if there are correlations between $\mathrm{CO}_{2}$ fluxes and air temperature or water level (cm below surface). Data from 2012 and 2011 after the treatments were started were used for these analyses. These NEE rates did not significantly correlate with either of the environmental parameters (Table 4).

A statistically significant interaction was found between time (year) and vegetation treatment $(\mathrm{p}=0.02)$ (Table 5). NEE rates from different vegetation treatments differed significantly from one another $(\mathrm{p}=0.024)$ (Table 6$)$ with sedge plots being different from Ericaceae plots (mean difference $-1.23 \mu \mathrm{mol} \mathrm{m}^{-2} \mathrm{~s}^{-1}, \mathrm{p}=0.046$ ). The difference between sedge and control plots was also nearly statistically different (mean difference $-1.18, \mathrm{p}=0.057)$. Neither the different water levels nor the combinations of water level and vegetation treatments showed any statistically significant difference between one another over the years. Additional repeated measures analysis showed NEE from sedge plots differed significantly between years 2010 and 2011 (mean difference $\left.2.67 \mu \mathrm{mol} \mathrm{m} \mathrm{m}^{-2} \mathrm{~s}^{-1}, \mathrm{p}=0.03\right)$. Control plots differed significantly between years 2011 and 2012 (mean difference $-0.93 \mu \mathrm{mol} \mathrm{m} \mathrm{s}^{-1}, \mathrm{p}=0.03$ ).

Stepwise multiple regressions found no correlation between the environmental parameters and high water level sedge plots in 2011 and 2012. For high water level Ericaceae plots in 2011 peat temperature at $40 \mathrm{~cm}$ seemed to best explain NEE values (model $\left.\mathrm{R}^{2}=59, \mathrm{p}=0.006\right)$ as well as for $2012\left(\right.$ model $\left.\mathrm{R}^{2}=0.59, \mathrm{p}=0.005\right)$. Peat temperatures explained high water level control plot NEE values in both 2011 and 2012: in 2011 the temperature at $40 \mathrm{~cm}$ was the best correlated (model $\mathrm{R}^{2}=0.78$, $\mathrm{p}<0.001)$ and in 2012 the temperature at $10 \mathrm{~cm}\left(\right.$ model $\left.\mathrm{R}^{2}=0.61, \mathrm{p}=0.005\right)$. Low water level sedge plot NEE values in 2011 correlated with water level (model $\mathrm{R}^{2}=0.67$, $\mathrm{p}=0.002$ ), whereas in 2012 no correlations between NEE and environmental parameters 
were found. No correlations were found between environmental parameters and low water level Ericaceae plots in either of the years. In 2011 low water level control plots did not correlate with the environmental parameters, but in 2012 peat temperature at 40 $\mathrm{cm}$ explained NEE values the best (model $\mathrm{R}^{2}=0.44, \mathrm{p}=0.026$ ).

\section{Ecosystem respiration}

The pattern of ER in each year can be seen in Figure 7. The ER values from 2010 are from the end of the summer, but they are within similar range than the values of 2012. The difference of 2011 compared to 2010 and 2012 can clearly be seen from the figure.

The mean ER flux rates for all the plots in 2010 were $-4.86 \pm 0.13 \mu \mathrm{mol} \mathrm{m}{ }^{-2}$ $\mathrm{s}^{-1}$ and in 2011 before the treatments were initiated they were $-2.24 \pm 0.23 \mu \mathrm{mol} \mathrm{m} \mathrm{s}^{-1}$. No differences between the plots were found before the treatments were started $(p=0.512$ for 2010 and $\mathrm{p}=0.572$ for 2011). The mean ER rates for control bins in 2011 after starting the treatments were $-2.48 \pm 0.49 \mu \mathrm{mol} \mathrm{m} \mathrm{m}^{-2} \mathrm{~s}^{-1}$ for high water level plots and -2.90 $\pm 0.54 \mu \mathrm{mol} \mathrm{m}^{-2} \mathrm{~s}^{-1}$ for low water level plots. In 2012 the rates were $-4.12 \pm 0.58 \mu \mathrm{mol} \mathrm{m}^{-}$ ${ }^{2} \mathrm{~s}^{-1}$ and $-4.29 \pm 0.57 \mu \mathrm{mol} \mathrm{m} \mathrm{s}^{-1}$, respectively. No significant effects of different water levels on the ER rates were found in 2012 (Figure 3 and 4) and there was also no interaction between water level and vegetation treatments. The vegetation treatments affected ER ( $\mathrm{p}=0.008)$, and sedge plots differed from both Ericaceae and control plots (mean difference 0.58 and $0.6049 \mu \mathrm{mol} \mathrm{m}^{-2} \mathrm{~s}^{-1}, \mathrm{p}=0.018$ and $\mathrm{p}=0.014$, respectively). The sedge plot ER rates were about $14 \%$ lower than those of Ericaceae and control plots. The ER of Ericaceae plots was $0.5 \%$ smaller compared to control plots. The high water level sedge plots had ER rates approximately $12 \%$ lower than the low water level sedge

plots and $18 \%$ lower than high water level control plots. The low water level sedge plots had ER rates $11 \%$ lower than low water level control plots. High water level Ericaceae 
plots had $2 \%$ lower ER rates than low water level and for control plots high water level ER rates were $4 \%$ lower than for low water level.

Control plots had higher ER rates in 2012 than in 2011 (Figure 5). The low water level ER rates were higher on both years. The regression analysis on the control plot ER rates and environmental parameters showed that ER correlated with air temperature and water level on both high and low water level plots in 2011 (after starting the treatments), but only with air temperature in 2012 (Table 4).

Statistically significant differences could be found in ER rates over time (year) (Table 5). Years 2010 and 2011 differed from each other (mean difference -2.52 $\mu \mathrm{mol} \mathrm{m} \mathrm{m}^{-2}, \mathrm{p}<0.001$ ) as well as years 2010 and 2012 (mean difference $-0.87 \mu \mathrm{mol} \mathrm{m}^{-2} \mathrm{~s}^{-}$ ${ }^{1}, \mathrm{p}=0.026$ ) and 2011 and 2012 (mean difference $1.65 \mu \mathrm{mol} \mathrm{m}^{-2} \mathrm{~s}^{-1}, \mathrm{p}<0.001$ ). No statistically significant interactions were found in the between-subjects factors (Table 6). Neither the vegetation treatments nor different water levels, or the combinations of these seemed to have any statistically significant effect on the ER rates over the years. Plots with Ericaceae removed had lowest ER rates in 2011 and 2012 and in general the ER rates were highest in 2010, followed by 2012 and being lowest in 2011.

Stepwise multiple regression analysis showed no correlations between environmental parameters and ER values in 2011 for high water level sedge plots. In 2012 peat temperatures at 20 and $5 \mathrm{~cm}$ explained ER values the best (model $\mathrm{R}^{2}=0.93$, $\mathrm{p}<0.001)$. Peat temperature at $5 \mathrm{~cm}$ and $20 \mathrm{~cm}$ explained the high water level Ericaceae plot ER values in 2011 and 2012, respectively (model $\mathrm{R}^{2}=0.84, \mathrm{p}<0.001$ in 2011 and model $\mathrm{R}^{2}=0.74, \mathrm{p}=0.001$ in 2012). The same pattern occurred with high water level control plots in 2011 and 2012 (model $\mathrm{R}^{2}=0.70, \mathrm{p}=0.001$ in 2011 , model $\mathrm{R}^{2}=0.69$, $p=0.002$ in 2012). Low water level sedge plot ER rates from 2011 did not correlate with the environmental parameters, but in 2012 peat temperature at $20 \mathrm{~cm}$ explained the rates the best (model $\mathrm{R}^{2}=0.64, \mathrm{p}=0.003$ ). Ecosystem respiration rates from low water level Ericaceae plots correlated the best with peat temperature at $5 \mathrm{~cm}$ in 2011 (model 
$\mathrm{R}^{2}=0.72, \mathrm{p}=0.001$ ), and in 2012 air temperature explained the rates the best (model $\mathrm{R}^{2}=0.76, \mathrm{p}<0.001$ ). The same pattern occurred with low water level control plots (model $\mathrm{R}^{2}=0.86, \mathrm{p}<0.001$ in 2011, model $\mathrm{R}^{2}=0.80, \mathrm{p}<0.001$ in 2012).

\section{Gross ecosystem production}

The different years and their sampling days can be seen in Figure 8 . Vegetation removal took place in the end of June 2011 and the effects of it to the GEP can be seen in graph b. The mean total GEP rates in 2010 and early 2011 (pre-treatments) were $9.93 \pm 0.19$ and $6.75 \pm 0.53 \mu \mathrm{mol} \mathrm{m}^{-2} \mathrm{~s}^{-1}$, respectively. No statistically significant differences were found between the plots before the treatments were started $(\mathrm{p}=0.259$ for 2010 and $\mathrm{P}=0.902$ for early 2011). After starting the treatments the mean GEP rates for control plots were $8.93 \pm 1.34$ and $9.06 \pm 1.25 \mu \mathrm{mol} \mathrm{m}^{-2} \mathrm{~s}^{-1}$ for high and low water level in 2011. In 2012 the rates were $10.75 \pm 1.50$ and $10.38 \pm 1.10 \mu \mathrm{mol} \mathrm{m}^{-2} \mathrm{~s}^{-1}$ for high and low water level. Water level did not have a significant effect on GEP rates in 2012 (Figure 3 and 4) and there was also no significant interaction between water level and vegetation treatments. The vegetation treatments caused difference in GEP rates $(\mathrm{p}<0.001)$. The sedge plots differed from both Ericaceae plots (mean difference -2.58 $\mu \mathrm{mol} \mathrm{m} \mathrm{m}^{-2}, \mathrm{p}=0.001$ ) and control plots (mean difference $-3.10 \mu \mathrm{mol} \mathrm{m}^{-2} \mathrm{~s}^{-1}, \mathrm{p}<0.001$ ). The GEP rates of sedge plots were about $26 \%$ lower than of Ericaceae plots and $29 \%$ lower than of control plots. The GEP rates of Ericaceae plots were $5 \%$ lower than of control plots. The high water level sedge plot GEP rates were about $12 \%$ lower than the rates of low water level sedge plots and $35 \%$ lower than the rates of high water level control plots. The low water level sedge plots had GEP $24 \%$ lower than low water level control plots. The high water level Ericaceae plots had GEP rates about $7 \%$ higher than low water level Ericaceae plots and high water level control plots had rates about $4 \%$ higher than low water level control plots. 
The analysis of control plots showed that GEP rates in 2011, after starting the treatments, were slightly higher on low water level plots (Figure 5). In 2012 this was reversed, as the high water level plots had higher GEP rates. The difference between these two water levels was also more clearly seen than in 2011. The simple linear regression analysis showed GEP rates from high water level plots correlated with air temperature and water level in 2011 (Table 4). In 2012 both high and low water level control plot GEP rates correlated with air temperature.

Gross ecosystem production differed significantly between different years $(\mathrm{p}<0.001)$ : year 2010 differed from 2011 (mean difference $3.00 \mu \mathrm{mol} \mathrm{m}^{-2} \mathrm{~s}^{-1}, \mathrm{p}<0.001$ ) and year 2011 differed from 2012 (mean difference $-2.43 \mu \mathrm{mol} \mathrm{m}^{-2} \mathrm{~s}^{-1}, \mathrm{p}<0.001$ ). Time (year) interacted significantly with vegetation treatment $(\mathrm{p}<0.001)$ (Table 5). Vegetation treatments differed significantly from each other $(\mathrm{p}=0.001)$, but no other treatment effects were detected (Table 6). Gross ecosystem production from sedge plots differed from Ericaceae plots (mean difference $-1.45 \mu \mathrm{mol} \mathrm{m}^{-2} \mathrm{~s}^{-1}, \mathrm{p}=0.049$ ). Separate repeated analysis on different treatments showed that all vegetation treatments differed over time (Figure 3). Sedge plots differed between years 2010 and 2011 (mean difference $5.67 \mu \mathrm{mol} \mathrm{m}^{-2} \mathrm{~s}^{-1}$, $\mathrm{p}<0.001$ ) and between 2011 and 2012 (mean difference $-2.32 \mu \mathrm{mol} \mathrm{m}^{-2} \mathrm{~s}^{-1}, \mathrm{p}=0.008$ ). Ericaceae plots had significant differences between 2010 and 2011 (mean difference 2.11 $\mu \mathrm{mol} \mathrm{m} \mathrm{m}^{-2} \mathrm{~s}^{-1}, \mathrm{p}=0.011$ ) as well as 2011 and 2012 (mean difference $-2.24 \mu \mathrm{mol} \mathrm{m}^{-2} \mathrm{~s}^{-1}$, $\mathrm{p}=0.007$ ). Control plots differed significantly between 2011 and 2012 (mean difference $\left.2.71 \mu \mathrm{mol} \mathrm{m} \mathrm{m}^{-2} \mathrm{~s}^{-1}, \mathrm{p}=0.001\right)$.

According to stepwise multiple regressions GEP rates from high water level sedge plots did not correlate with the environmental parameters in 2011 and 2012. High water level Ericaceae plot GEP from 2011 were explained by air temperature (model $\mathrm{R}^{2}=0.72, \mathrm{p}=0.001$ ) and in 2012 by peat temperature at $20 \mathrm{~cm}$ (model $\mathrm{R}^{2}=0.85$, $\mathrm{p}<0.001)$. The high water level control plot GEP rates were best correlated with peat temperature at $20 \mathrm{~cm}$ in both 2011 and 2012 (model $\mathrm{R}^{2}=0.78, \mathrm{p}<0.001$ in 2011, model $\mathrm{R}^{2}=0.83, \mathrm{p}<0.001$ in 2012). Low water level sedge plots from 2011 correlated the most 
with water level (model $\mathrm{R}^{2}=0.64, \mathrm{p}=0.003$ ) and from 2012 with peat temperature at 20 $\mathrm{cm}$ (model $\mathrm{R}^{2}=0.41, \mathrm{p}=0.035$ ). The low water level Ericaceae plot GEP rates correlated the most with peat temperature at $5 \mathrm{~cm}$ in 2011 (model $\mathrm{R}^{2}=0.51, \mathrm{p}=0.014$ ) and with air temperature in 2012 (model $\mathrm{R}^{2}=0.85, \mathrm{p}<0.001$ in 2012). Low water level control bins in 2011 were best explained by peat temperature at $40 \mathrm{~cm}$ (model $\left.\mathrm{R}^{2}=0.46, \mathrm{p}=0.022\right)$ and in 2012 by peat temperature at $20 \mathrm{~cm}\left(\operatorname{model} \mathrm{R}^{2}=0.79, \mathrm{p}<0.001\right)$.

\section{Discussion}

\section{Differences in NEE, ER and GEP between treatments and over time}

Our ER rates are within the same range as ER rates measured in similar systems. A study using experimental temperature and water level manipulations in a rich fen in Alaska (Chivers et al. 2009) reported ER rates varying approximately between -3.5 and $-4 \mu \mathrm{mol} \mathrm{m} \mathrm{m}^{-2}$ depending on the treatment. The NEE rates of the same study were low compared to ours (approximately between -0.5 to $2 \mu \mathrm{mol} \mathrm{m}^{-2} \mathrm{~s}^{-1}$ ) but GEP was close to ours with rates of approximately between 4 and $8 \mu \mathrm{mol} \mathrm{m}^{-2} \mathrm{~s}^{-1}$. The vegetation and nutrient status of the peatland in the study of (Chivers et al. 2009) was different than in our study, however. The site on the study by (Treat et al. 2007), a poor fen, had similar vegetation to our site. The seasonal NEE rates varied between 5 and $7 \mu \mathrm{mol} \mathrm{m}^{-2} \mathrm{~s}^{-1}$, ER rates between -4.8 and $-7.5 \mu \mathrm{mol} \mathrm{m} \mathrm{m}^{-2} \mathrm{~s}^{-1}$ and GEP rates between 10.5 and $15 \mu \mathrm{mol} \mathrm{m} \mathrm{m}^{-2} \mathrm{~s}^{-1}$, which again are within similar rage to our results. The study by Turetsky et al. (2002) reported lower ER rates than ours.

The GEP rates at a poor sedge-dominated fen have been reported to be higher in the drained conditions than at natural conditions (Strack et al. 2006), thus our results from sedge treatment plots support this. In general, the results from examining the 
relationship of GEP and water level position vary. In some studies, GEP rates have been found to increase with lower water level (e.g. Laiho 2006; Ballantyne et al. unpublished). However, if the water level drops too low the plants may suffer from drought stress and their production decreases (Weltzin et al. 2000). The ER rates were all lower from high water level compared to low water level. The biggest difference between high and low water level ER rates was found in sedge plots, though none of these differences were statistically significant.

Many studies have found that water level is an important regulator of peatland $\mathrm{CO}_{2}$ dynamics and that high water levels in general reduce $\mathrm{CO}_{2}$ emissions, whereas low water levels increase them because the aerobic peat layer is thicker (Moore and Knowles 1989; Silvola et al. 1996; Goulden and Crill 1997; Komulainen et al. 1999; Whalen 2005; Chivers et al. 2009). For instance, a study conducted in a subalpine fen in Colorado (Chimner 2003) found the $\mathrm{CO}_{2}$ emissions doubled when the water table was 0$5 \mathrm{~cm}$ below surface compared to a situation where it was $6-10 \mathrm{~cm}$ above the surface. A peatland restoration study at drained fen and bog sites in Finland (Komulainen et al. 1999) recorded $\mathrm{CO}_{2}$ emissions from untreated plots to be twice as high as from rewetted plots. The ER rates also decreased from rewetted plots after all the vegetation was removed. In addition a laboratory study focusing on the influences of water levels on peatland $\mathrm{CO}_{2}$ and $\mathrm{CH}_{4}$ emissions found dried peatlands to release more $\mathrm{CO}_{2}$ at least in the short term compared to the ones with high water level (Moore and Knowles 1989). Longterm water table drawdown was found to affect peatland $\mathrm{CO}_{2}$ fluxes even 80 years after the disturbance in a study of (Ballantyne et al. unpublished) conducted on a peatland in Northern Michigan. The ER and GEP rates both decreased when water levels were raised approximately $10 \mathrm{~cm}$ and increased on the site where water level was lowered with approximately $15 \mathrm{~cm}$. However, some long-term studies have shown an opposite result. The $\mathrm{CO}_{2}$ emissions of a peatland, where water levels were lower, have not increased compared to high water level peatlands because of increased photosynthesis rates caused by lower water level (Flanagan and Syed 2011). In Finland, where many peatlands have 
been drained for forestry, it has been discovered that many of the drained peatlands have continued to be carbon sinks after drainage due to increased production from the growing trees (Minkkinen et al. 2002).

A water manipulation study in an Alaskan bog also found that water table was not significant in predicting $\mathrm{CO}_{2}$ emissions (Turetsky et al. 2002). Substrate quality and the properties of soil were found to be important among with hydrological conditions and temperature in soil respiration rates in a modeling study of $\mathrm{C}$ and $\mathrm{N}$ mineralization of northern wetlands (Updegraff et al. 1995). According to the study local variations in soil properties and wetland type should be taken into consideration when projecting the study results to a larger scale because they could have an effect on the soil respiration that can't be explained with hydrological and temperature conditions.

\section{Vegetation and $\mathrm{CO}_{2}$ dynamics}

Ericaceous shrubs form a symbiosis with mycorrhiza fungi in their roots, which help them to scavenge nutrients from the soil (Largent et al. 1980; Andersen et al. 2010). Studies suggest that because of the efficient uptake of nutrients, mycorrhiza are strongly competitive and may prevent or at least restrict the saprophytes of the soil from using nutrients. This slows down the decomposition rate of peat (Read et al. 2004), which could lead to higher peat accumulation at Ericaceae-dominated peatlands compared to sedge-dominated peatlands. Sphagnum species, which are capable of living in highly nutrient poor conditions (Clymo 1970) are the primary peat formers in shrub-dominated bogs (Van Breemen 1995). Although some evidence of sedges having mycorrhiza has been found (Miller et al. 1999) C.oligosperma is not known to have any. The aerenchyma tissue of sedges helps them to bring oxygen from the atmosphere down to the rhizosphere and therefore accelerates the peat decomposition (Laine et al. 2000). The previous studies support that sedges are important in peatland $\mathrm{CO}_{2}$ dynamics, and our results confirmed 
that their aboveground biomass increased in the plots where only sedges were growing. Yet, our results also imply that role of Ericaceae is influential because the removal of sedges didn't change any NEE, ER or GEP rates significantly compared to control plots, unlike the shrub removal did.

The Ericaceae removal caused NEE, ER and GEP all to decrease compared to sedge removal and control plots, whereas sedge removal plots were not significantly different compared to control plots. The results imply that Ericaceous shrubs may have an important role in $\mathrm{CO}_{2}$ dynamics in this type of peatland. It is also possible, that the amount of biomass removed in the Ericaceae removal is more important than the species themselves. The shrub removal also caused more damage to the soil than the sedge removal. The lowered NEE and GEP rates of sedge treatment compared to the other plots, could be caused by a loss of plant biomass (Potvin et al. unpublished data), which reduces the amount of photosynthesizing plants. Plant biomass is related to the photosynthesis rate of a plant (Lambers et al. 2008). However, if we look at the aboveground biomass of $C$. oligosperma in both water levels of sedge plots (Table 6) we see that the biomass of both living and senesced sedges is almost $70 \%$ greater in low water level than high water level. Sedges have been shown to increase their above and belowground biomass and production in low water levels if shrubs are not present (Strack et al. 2006). Altogether the sedge biomass, including living and senesced plants, of sedge plots was almost $90 \%$ greater than the sedge biomass of control plots in 2012 . The removal of Ericaceae may have increased the saprophyte activity of the peat and released nutrients for sedges to use up, which results in their increased aboveground biomass in the sedge plots. As Table 2 shows the percentage cover of $C$. oligosperma was higher on low water level bins compared to high water level. The sedge coverage was, however, largest in the low water level control plots. The aboveground biomasses of Ericaceae did not differ as radically between different water levels: the biomass of high water level Ericaceae plots was approximately $2 \%$ smaller than low water level Ericaceae plots. 
There were no radical differences between the control plots and Ericaceae treatment either, although the shrub biomass was about $7 \%$ higher in Ericaceae treatment plots.

The autotrophic respiration rates of different plant groups were not measured in this study and previous studies have shown the ER rates of mosses can be high. A study on $\mathrm{CO}_{2}$ exchange of the moss surface conducted in black spruce forest Goulden and Crill (1997) showed the respiration from moss surface can account for 50$90 \%$ of the respiration of the whole forest. In the study feather mosses had higher respiration rates than Sphagnum, but this was believed to occur because the feather moss sites had black spruce growing on them and hence received carbon input from the trees, whereas Sphagnum mosses were growing on more open areas. By comparing the GEP rates of different vegetation treatments from 2012 it was possible to estimate that mosses accounted for approximately $65.5 \%$, shrubs $29.3 \%$ and sedges $5.2 \%$ to GEP. In the study of (Goulden and Crill 1997) mosses contributed 10-50 \% of whole forest GEP, depending on the growing conditions. The lowest rates were detected from shaded sites. The moss GEP rates have been shown to correlate negatively with the leaf area index (LAI) of vascular plants on the same site (Douma et al. 2007).

\section{Environmental parameters and NEE, ER and GEP}

Ecosystem respiration has been shown to be dependent on temperature ( Updegraff et al. 1995; Moore et al. 1998). Warming manipulation studies have shown the ER rates to increase along with the warmer temperature (Updegraff et al. 1995; Silvola et al. 1996). In our study air temperature correlated with ER rates but it was the best possible predictor only for ER and GEP rates of low water level Ericaceae plots in 2012 and high water level Ericaceae plots in 2011. Peat temperature was correlated with ER rates in all the other treatments except high and low water level sedge plots in 2011, which could not be predicted by any of the environmental parameters. The warmest peat 
temperatures are the ones that best explain the ER values in the treatments where correlation was found (Figure 2).

The correlations between peat temperatures and NEE were few and they differed between 2011 and 2012. As Figure 2 shows some of the lower measuring points had higher temperatures than the point closer to the surface in 2012, which was not the case in 2011. The height of water levels in 2012 (Figure 1) could explain why the peat was warmest at $20 \mathrm{~cm}$ below surface in most treatments and this temperature correlated so well with the ER rates. During the warmest time of the summer the water levels in both high and low water level bins were at their lowest. The low water level plots had their water level below $20 \mathrm{~cm}$ peat depth for quite a long time period, from July until the end of the samplings, except for a couple of days in July when it was at $20 \mathrm{~cm}$. From mid-July until the end of the samplings the lowest water levels for low water level plots were above $20 \mathrm{~cm}$ but mostly below $10 \mathrm{~cm}$ and at some point even lower than $15 \mathrm{~cm}$. This means that the $20 \mathrm{~cm}$ temperature sensor was the highest temperature sensor under water and inside saturated peat during most of the summer. The wet peat reserves heat better than dry peat, because its thermal conductivity is higher than that of dry peat (Kujala et al. 2008), so the highest parts of saturated peat were the warmest. The top $5 \mathrm{~cm}$ peat layer was the most susceptible to air temperature and therefore it was warmer than the peat at $10 \mathrm{~cm}$ below surface, which was at times saturated and at times dry. In 2011 such a pattern with the mean peat temperatures did not occur. The temperatures decreased the deeper they had been measured during the sampling season. This was probably because the water level treatments lasted for such a short time before the water levels were elevated again.

According to our results air and peat temperatures were positively correlated with each other. Other studies have reported similar results (Turetsky et al. 2002). Turetsky et al. (2002) found a negative correlation between water table levels and air temperature. 
The mean air temperature in 2012 was $1.0^{\circ} \mathrm{C}$ higher than in 2011 . Air temperature does not explain the flux rates in most cases, but it has an effect on the peat temperatures. The mean peat temperatures of all treatments together were higher in 2012 at all depths compared to 2011 temperatures expect for the two top measuring points: at 5 $\mathrm{cm}$ below surface temperatures were the same in both years and in $10 \mathrm{~cm}$ the temperature of 2012 was $0.5^{\circ} \mathrm{C}$ lower than it was in 2011 .

Both years 2011 and 2012 had approximately same amount of rainy days during the sampling season and the sum of rainfall was similar as well. Sampling during the rain was avoided because the EGM-4 does not hold water. Average wind speeds were almost equal in both years. Windy days were avoided for sampling, because the accuracy of chamber measurements declines due to pressure changes inside the chamber caused by wind turbulence (Davidson 2002). However, there may be small differences between the flux rates from 2011 and 2012 because there were some issues with the sealing of the bins to the chamber in 2011, so small leakages are possible. In the beginning of 2012 the seals were replaced with better, heavy duty cell foam to diminish the possibility of leakages. The average PAR rates for both 2011 and 2012 are similar, though there might be some changes between different days as cloudy days were not completely avoided. However, the sampling days were chosen so that the conditions stayed as similar as possible during the day.

\section{Conclusions}

Air temperature affected peat temperature and peat temperature was positively correlated with ER rates, which has been the case in previous studies as well (Turetsky et al. 2002). Some correlations were found in between NEE and GEP rates from low water level sedge plots and water level position in 2011, but otherwise the water level treatments had no significant effect on NEE, ER or GEP by year. The 
difference caused by vegetation treatments could easily be observed and water level also caused some changes in 2012 though they were not statistically significant. This differs from previous study results, which have reported water level to influence NEE, ER and GEP rates (Komulainen et al. 1999; Chimner 2003; Chivers et al. 2009). There has been some research on the importance of substrate quality and wetland type, which should be taken into consideration along with hydrology and temperature of the site (Updegraff et al. 1995).

Removing Ericaceae decreased NEE, ER and GEP rates rather dramatically compared to control plots and those where sedges were removed, although the aboveground biomass of sedges was found to be higher in sedge plots than control plots. It was also higher on low water level compared to high water level, like previous studies conducted in similar conditions have shown (Strack et al. 2006). The competition for nutrients between sedges and shrubs in the control plots may hold back the sedge growth. Shading could also be a reason to this as well as the water level: the differences between GEP rates between high and low control plots were relatively small. Removing Ericaceae increased sedge growth, but lowering the water level enhanced this effect. The increased growth of sedges in sedge plots could not compensate the loss of plant material resulted from Ericaceae removal, which is probably why the gas flux rates of sedge plots were low compared to other treatments. Sedge removal did not have a significant effect on NEE, ER or GEP compared to control plots, which confirms the important role of Ericaceae in peatland $\mathrm{CO}_{2}$ cycle. The data for this study was collected during a 3-year time period, of which the last year is the first one showing the actual effects of the different treatments. This is a relatively short time period, but as a long-term study on a Northern Michigan peatland (Ballantyne et al. unpublished) found, the short-term studies may be accurate in predicting the long-term effects. 


\section{Tables}

Table 1.The correlations between air temperature and peat temperatures on different depths below surface $(5,10,20,40$ and $80 \mathrm{~cm})$ by treatment in 2011 and $2012 . \mathrm{H}=$ high water level, $\mathrm{L}=$ low water level, $\mathrm{S}=$ Ericaceae removed, $\mathrm{E}=$ sedges removed, $\mathrm{C}=$ control. The $\mathrm{p}$-value is in parentheses.

\begin{tabular}{|c|c|c|c|c|c|c|}
\hline 2011 & & T5 & T10 & T20 & $\mathrm{T} 40$ & T80 \\
\hline Air temperature & HS & $0.95(<0.001)$ & $0.93(<0.001)$ & $0.91(<0.001)$ & $0.85(0.001)$ & $0.79(0.002)$ \\
\hline & LS & $0.95(<0.001)$ & $0.93(<0.001)$ & $0.90(<0.001)$ & $0.82(0.001)$ & $0.78(0.002)$ \\
\hline & HE & $0.93(<0.001)$ & $0.93(<0.001)$ & $0.89(<0.001)$ & $0.78(0.002)$ & $0.77(0.003)$ \\
\hline & LE & $0.93(<0.001)$ & $0.93(<0.001)$ & $0.90(<0.001)$ & $0.84(0.001)$ & $0.79(0.003)$ \\
\hline & $\mathrm{HC}$ & $0.94(<0.001)$ & $0.92(<0.001)$ & $0.89(<0.001)$ & $0.80(0.002)$ & $0.78(0.002)$ \\
\hline & LC & $0.93(<0.001)$ & $0.90(<0.001)$ & $0.89(<0.001)$ & $0.80(0.001)$ & $0.78(0.002)$ \\
\hline 2012 & & $\mathrm{T5}$ & $\mathrm{T} 10$ & $\mathrm{~T} 20$ & $\mathrm{~T} 40$ & $\mathrm{~T} 80$ \\
\hline Air temperature & HS & $0.88(<0.001)$ & $0.84(0.001)$ & $0.87(<0.001)$ & $0.86(<0.001)$ & $0.83(0.001)$ \\
\hline & LS & $0.89(<0.001)$ & $0.87(<0.001)$ & $0.88(<0.001)$ & $0.87(<0.001)$ & $0.83(0.001)$ \\
\hline & HE & $0.88(<0.001)$ & $0.85(<0.001)$ & $0.85(<0.001)$ & $0.85(<0.001)$ & $0.84(0.001)$ \\
\hline & LE & $0.88(<0.001)$ & $0.85(<0.001)$ & $0.87(<0.001)$ & $0.88(<0.001)$ & $0.84(0.001)$ \\
\hline & $\mathrm{HC}$ & $0.89(<0.001)$ & $0.86(<0.001)$ & $0.88(<0.001)$ & $0.86(<0.001)$ & $0.84(0.001)$ \\
\hline & LC & $0.89(<0.001)$ & $0.84(<0.001)$ & $0.88(<0.001)$ & $0.86(<0.001)$ & $0.84(0.001)$ \\
\hline
\end{tabular}


Table 2. Mean percentage cover of plant species on different treatments in 2010-2012

High water level

\begin{tabular}{|c|c|c|c|c|c|c|}
\hline 2010 & Sedge & Ericaceae & Control & Sedge & Ericaceae & Control \\
\hline Carex oligosperma & $32.0 \%$ & $19.9 \%$ & $28.5 \%$ & $48.8 \%$ & $32.0 \%$ & $36.7 \%$ \\
\hline $\begin{array}{l}\text { Chamaedaphne } \\
\text { calyculata }\end{array}$ & $50.0 \%$ & $42.2 \%$ & $36.7 \%$ & $51.2 \%$ & $39.5 \%$ & $29.3 \%$ \\
\hline Kalmia polifolia & $19.1 \%$ & $32.0 \%$ & $29.7 \%$ & $56.3 \%$ & $37.1 \%$ & $41.4 \%$ \\
\hline Ledum groenlandicum & $1.2 \%$ & $0.0 \%$ & $0.0 \%$ & $3.5 \%$ & $0.4 \%$ & $0.0 \%$ \\
\hline Vaccinium oxycoccos & $70.3 \%$ & $100.8 \%$ & $84.4 \%$ & $112.9 \%$ & $103.1 \%$ & $91.0 \%$ \\
\hline Andromeda polifolia & $0.4 \%$ & $0.0 \%$ & $0.0 \%$ & $0.0 \%$ & $0.0 \%$ & $0.8 \%$ \\
\hline Polytrichum strictum & $27.7 \%$ & $21.9 \%$ & $31.6 \%$ & $35.5 \%$ & $23.4 \%$ & $20.7 \%$ \\
\hline $\begin{array}{l}\text { Sphagnum fuscum } \\
\text { Sphagnum }\end{array}$ & $23.8 \%$ & $17.6 \%$ & $22.7 \%$ & $9.0 \%$ & $19.9 \%$ & $14.1 \%$ \\
\hline magellanicum & $12.1 \%$ & $13.3 \%$ & $15.2 \%$ & $10.2 \%$ & $10.2 \%$ & $11.7 \%$ \\
\hline Sphagnum rubellum & $62.1 \%$ & $61.7 \%$ & $54.7 \%$ & $69.9 \%$ & $57.8 \%$ & $60.9 \%$ \\
\hline Sphagnum species & $0.4 \%$ & $0.0 \%$ & $0.0 \%$ & $0.4 \%$ & $0.0 \%$ & $0.0 \%$ \\
\hline \multicolumn{7}{|l|}{2011} \\
\hline Carex oligosperma & $34.4 \%$ & $0.4 \%$ & $14.5 \%$ & $37.9 \%$ & $0.4 \%$ & $18.4 \%$ \\
\hline $\begin{array}{l}\text { Chamaedaphne } \\
\text { calyculata }\end{array}$ & $1.2 \%$ & $26.2 \%$ & $34.0 \%$ & $0.4 \%$ & $43.4 \%$ & $24.2 \%$ \\
\hline Kalmia polifolia & $1.6 \%$ & $28.5 \%$ & $23.0 \%$ & $0.0 \%$ & $32.4 \%$ & $24.2 \%$ \\
\hline Ledum groenlandicum & $0.0 \%$ & $0.0 \%$ & $0.0 \%$ & $0.0 \%$ & $0.0 \%$ & $0.0 \%$ \\
\hline Vaccinium oxycoccos & $4.3 \%$ & $91.0 \%$ & $47.3 \%$ & $11.3 \%$ & $64.8 \%$ & $49.2 \%$ \\
\hline Andromeda polifolia & $0.0 \%$ & $0.0 \%$ & $0.0 \%$ & $0.0 \%$ & $0.4 \%$ & $0.0 \%$ \\
\hline Polytrichum strictum & $26.6 \%$ & $15.6 \%$ & $20.7 \%$ & $32.8 \%$ & $26.6 \%$ & $20.7 \%$ \\
\hline $\begin{array}{l}\text { Sphagnum fuscum } \\
\text { Sphagnum }\end{array}$ & $33.6 \%$ & $38.3 \%$ & $23.8 \%$ & $18.0 \%$ & $38.7 \%$ & $23.8 \%$ \\
\hline magellanicum & $8.6 \%$ & $10.5 \%$ & $17.2 \%$ & $7.4 \%$ & $8.6 \%$ & $9.0 \%$ \\
\hline Sphagnum rubellum & $53.9 \%$ & $56.6 \%$ & $60.2 \%$ & $55.9 \%$ & $50.8 \%$ & $65.2 \%$ \\
\hline Sphagnum species & $2.0 \%$ & $0.4 \%$ & $0.4 \%$ & $2.7 \%$ & $0.8 \%$ & $1.2 \%$ \\
\hline \multicolumn{7}{|l|}{2012} \\
\hline Carex oligosperma & $17.6 \%$ & $0.0 \%$ & $14.8 \%$ & $19.5 \%$ & $0.0 \%$ & $27.0 \%$ \\
\hline $\begin{array}{l}\text { Chamaedaphne } \\
\text { calyculata }\end{array}$ & $0.0 \%$ & $30.1 \%$ & $28.5 \%$ & $0.0 \%$ & $48.4 \%$ & $30.5 \%$ \\
\hline Kalmia polifolia & $0.0 \%$ & $16.4 \%$ & $22.7 \%$ & $0.0 \%$ & $30.1 \%$ & $25.4 \%$ \\
\hline Ledum groenlandicum & $0.0 \%$ & $0.0 \%$ & $0.0 \%$ & $0.0 \%$ & $0.4 \%$ & $0.0 \%$ \\
\hline Vaccinium oxycoccos & $0.0 \%$ & $45.3 \%$ & $33.2 \%$ & $0.0 \%$ & $69.1 \%$ & $57.0 \%$ \\
\hline Polytrichum strictum & $37.5 \%$ & $8.2 \%$ & $10.9 \%$ & $49.6 \%$ & $25.0 \%$ & $16.0 \%$ \\
\hline $\begin{array}{l}\text { Sphagnum fuscum } \\
\text { Sphagnum }\end{array}$ & $18.4 \%$ & $18.8 \%$ & $12.1 \%$ & $23.8 \%$ & $33.2 \%$ & $25.8 \%$ \\
\hline magellanicum & $10.9 \%$ & $21.9 \%$ & $19.1 \%$ & $23.0 \%$ & $17.6 \%$ & $17.2 \%$ \\
\hline Sphagnum rubellum & $78.9 \%$ & $74.2 \%$ & $75.8 \%$ & $56.6 \%$ & $51.2 \%$ & $57.4 \%$ \\
\hline Sphagnum species & $1.2 \%$ & $0.0 \%$ & $0.0 \%$ & $1.2 \%$ & $0.4 \%$ & $0.0 \%$ \\
\hline
\end{tabular}


Table 3. Aboveground biomass ( $\mathrm{g} / \mathrm{m} 2)$ living/senesced plants for different plots in 2012 . If the value is missing, there were no senesced plants of said species. The water level was high in bins $1,2,3,8,10,12,15,16,17,19,20$ and 21 and low in bins 4, 5, 6, 7, 9, 11, $13,14,18,22,23$ and 24.

\begin{tabular}{lcccccccc}
\hline S plots: & $\mathbf{1}$ & $\mathbf{5}$ & $\mathbf{7}$ & $\mathbf{1 2}$ & $\mathbf{1 7}$ & $\mathbf{1 8}$ & $\mathbf{2 1}$ & $\mathbf{2 3}$ \\
\hline \hline C.oligosperma & $9.2 / 5.2$ & $6.3 / 14.2$ & $33.2 / 28.3$ & $22.7 / 11.8$ & $23.5 / 11.0$ & $51.3 / 16.7$ & $0.5 / 13.0$ & $6.7 / 6.9$ \\
& & & & & & & & \\
E plots: & $\mathbf{2}$ & $\mathbf{6}$ & $\mathbf{1 0}$ & $\mathbf{1 1}$ & $\mathbf{1 3}$ & $\mathbf{1 6}$ & $\mathbf{2 0}$ & $\mathbf{2 2}$ \\
\hline \hline C.calyculata & $120.8 /-$ & $99.1 /-$ & $79.5 /-$ & $76.5 /-$ & $75.1 /-$ & $63.0 /-$ & $134.6 /-$ & $109.1 /-$ \\
K. Polifolia & $15.9 /-$ & $26.3 /-$ & $19.4 /-$ & $34.1 /-$ & $20.7 /-$ & $38.1 /-$ & $30.0 /-$ & $72.8 /-$ \\
& & & & & & & & \\
C plots: & $\mathbf{3}$ & $\mathbf{4}$ & $\mathbf{8}$ & $\mathbf{9}$ & $\mathbf{1 4}$ & $\mathbf{1 5}$ & $\mathbf{1 9}$ & $\mathbf{2 4}$ \\
\hline \hline C.oligosperma & $0.8 / 0.6$ & $29.8 / 10.1$ & $20.6 / 7.2$ & $4.4 / 2.4$ & $3.7 / 2.1$ & $0.5 / 2.4$ & $28.1 / 4.0$ & $16.2 / 5.7$ \\
C.calyculata & $131.1 /-$ & $30.2 /-$ & $64.2 /-$ & $101.7 /-$ & $138.7 /-$ & $62.8 /-$ & $125.0 /-$ & $71.6 /-$ \\
K. Polifolia & $23.5 /-$ & $34.6 /-$ & $18.6 /-$ & $17.3 /-$ & $28.9 /-$ & $40.0 /-$ & $28.0 /-$ & $26.1 /-$ \\
\hline
\end{tabular}


Table 4. The correlations of $\mathrm{CO}_{2}$ flux of the control plots and air temperature and water level for 2011 after starting the treatments and 2012. The p-value is in the parenthesis. Bold values denote p-values below 0.05 .

\begin{tabular}{|c|c|c|c|}
\hline 2011 & & $\begin{array}{c}\text { Air } \\
\text { temperature } \\
\end{array}$ & $\begin{array}{c}\text { Water level (cm below } \\
\text { surface) }\end{array}$ \\
\hline \multirow[t]{3}{*}{ High wt } & NEE & $0.54(0.059)$ & $0.42(0.11)$ \\
\hline & ER & $0.73(0.015)$ & $0.69(0.021)$ \\
\hline & GEP & $0.71(0.017)$ & $0.58(0.048)$ \\
\hline \multirow[t]{3}{*}{ Low wt } & NEE & $0.022(0.75)$ & $0.00(0.99)$ \\
\hline & ER & $0.79(0.007)$ & $0.68(0.022)$ \\
\hline & GEP & $0.013(0.81)$ & $0.036(0.68)$ \\
\hline \multicolumn{4}{|l|}{2012} \\
\hline \multirow[t]{3}{*}{ High wt } & NEE & $0.25(0.12)$ & $0.008(0.80)$ \\
\hline & ER & $0.67(0.002)$ & $0.22(0.14)$ \\
\hline & GEP & $0.57(0.007)$ & $0.096(0.35)$ \\
\hline \multirow[t]{3}{*}{ Low wt } & NEE & $0.32(0.07)$ & $0.067(0.44)$ \\
\hline & ER & $0.80(<0.001)$ & $0.16(0.23)$ \\
\hline & GEP & $0.75(0.001)$ & $0.15(0.24)$ \\
\hline
\end{tabular}


Table 5. Within-subjects effects of the repeated measures analysis. Greenhouse-Geisser corrected values were used because sphericity could not be assumed with p-value 0.05.

\begin{tabular}{|c|c|c|c|c|c|c|}
\hline & & $\begin{array}{l}\text { Type III Sum } \\
\text { of Squares }\end{array}$ & $\mathrm{df}$ & Mean Square & $\mathrm{F}$ & $\mathrm{P}$-value \\
\hline \multicolumn{7}{|l|}{ NEE } \\
\hline Year & $\begin{array}{l}\text { Greenhouse- } \\
\text { Geisser }\end{array}$ & 7.168 & 1.265 & 5.668 & 2.753 & .104 \\
\hline $\begin{array}{l}\text { Year * Water } \\
\text { Table Level }\end{array}$ & $\begin{array}{l}\text { Greenhouse- } \\
\text { Geisser }\end{array}$ & .155 & 1.265 & .123 & .060 & .863 \\
\hline $\begin{array}{l}\text { Year * Vegetation } \\
\text { treatment }\end{array}$ & $\begin{array}{l}\text { Greenhouse- } \\
\text { Geisser }\end{array}$ & 36.669 & 2.529 & 14.499 & 7.041 & .002 \\
\hline $\begin{array}{l}\text { Year * Water } \\
\text { Table Level * } \\
\text { Vegetation } \\
\text { Treatment }\end{array}$ & $\begin{array}{l}\text { Greenhouse- } \\
\text { Geisser }\end{array}$ & .709 & 2.529 & .280 & .136 & .914 \\
\hline \multicolumn{7}{|l|}{$\overline{E R}$} \\
\hline Year & $\begin{array}{l}\text { Greenhouse- } \\
\text { Geisser }\end{array}$ & 78.673 & 1.160 & 67.841 & 53.353 & $<.001$ \\
\hline $\begin{array}{l}\text { Year * Water } \\
\text { Table Level }\end{array}$ & $\begin{array}{l}\text { Greenhouse- } \\
\text { Geisser }\end{array}$ & .272 & 1.160 & .235 & .185 & .709 \\
\hline $\begin{array}{l}\text { Year * Vegetation } \\
\text { treatment }\end{array}$ & $\begin{array}{l}\text { Greenhouse- } \\
\text { Geisser }\end{array}$ & 4.709 & 2.319 & 2.030 & 1.597 & .225 \\
\hline $\begin{array}{l}\text { Year * Water } \\
\text { Table Level * } \\
\text { Vegetation } \\
\text { Treatment }\end{array}$ & $\begin{array}{l}\text { Greenhouse- } \\
\text { Geisser }\end{array}$ & 2.961 & 2.319 & 1.277 & 1.004 & .394 \\
\hline \multicolumn{7}{|l|}{ GEP } \\
\hline Year & $\begin{array}{l}\text { Greenhouse- } \\
\text { Geisser }\end{array}$ & 121.878 & 1.410 & 86.461 & 38.485 & $<.001$ \\
\hline $\begin{array}{l}\text { Year * Water } \\
\text { Table Level }\end{array}$ & $\begin{array}{l}\text { Greenhouse- } \\
\text { Geisser }\end{array}$ & .105 & 1.410 & .074 & .033 & .924 \\
\hline $\begin{array}{l}\text { Year * Vegetation } \\
\text { treatment }\end{array}$ & $\begin{array}{l}\text { Greenhouse- } \\
\text { Geisser }\end{array}$ & 63.166 & 2.819 & 22.405 & 9.973 & $<.001$ \\
\hline $\begin{array}{l}\text { Year * Water } \\
\text { Table Level * } \\
\text { Vegetation } \\
\text { Treatment }\end{array}$ & $\begin{array}{l}\text { Greenhouse- } \\
\text { Geisser }\end{array}$ & 2.163 & 2.819 & .767 & .342 & .784 \\
\hline
\end{tabular}


Table 6. Between-subject effects of the repeated measures analysis.

\begin{tabular}{|c|c|c|c|c|c|}
\hline & $\begin{array}{l}\text { Type III } \\
\text { Sum of } \\
\text { Squares }\end{array}$ & $\mathrm{df}$ & $\begin{array}{l}\text { Mean } \\
\text { Square }\end{array}$ & $\mathrm{F}$ & $\mathrm{P}$-value \\
\hline \multicolumn{6}{|l|}{ NEE } \\
\hline Water Table & .661 & 1 & .661 & .264 & .614 \\
\hline Level & & & & & \\
\hline Vegetation & 23.163 & 2 & 11.582 & 4.618 & .024 \\
\hline Treatment & & & & & \\
\hline $\begin{array}{l}\text { Water Table } \\
\text { Level * } \\
\text { Vegetation } \\
\text { Treatment }\end{array}$ & 2.650 & 2 & 1.325 & .528 & .599 \\
\hline \multicolumn{6}{|l|}{$\overline{E R}$} \\
\hline $\begin{array}{l}\text { Water Table } \\
\text { Level }\end{array}$ & 1.032 & 1 & 1.032 & 1.282 & .272 \\
\hline $\begin{array}{l}\text { Vegetation } \\
\text { Treatment }\end{array}$ & .636 & 2 & .318 & .394 & .680 \\
\hline $\begin{array}{l}\text { Water Table } \\
\text { Level * } \\
\text { Vegetation } \\
\text { Treatment }\end{array}$ & 1.794 & 2 & .897 & 1.114 & .350 \\
\hline \multicolumn{6}{|l|}{$\overline{\text { GEP }}$} \\
\hline $\begin{array}{l}\text { Water Table } \\
\text { Level }\end{array}$ & .008 & 1 & .008 & .002 & .964 \\
\hline $\begin{array}{l}\text { Vegetation } \\
\text { Treatment }\end{array}$ & 31.630 & 2 & 15.815 & 4.391 & .028 \\
\hline $\begin{array}{l}\text { Water Table } \\
\text { Level * } \\
\text { Vegetation } \\
\text { Treatment }\end{array}$ & 5.122 & 2 & 2.561 & .711 & .504 \\
\hline
\end{tabular}




\section{Figures}
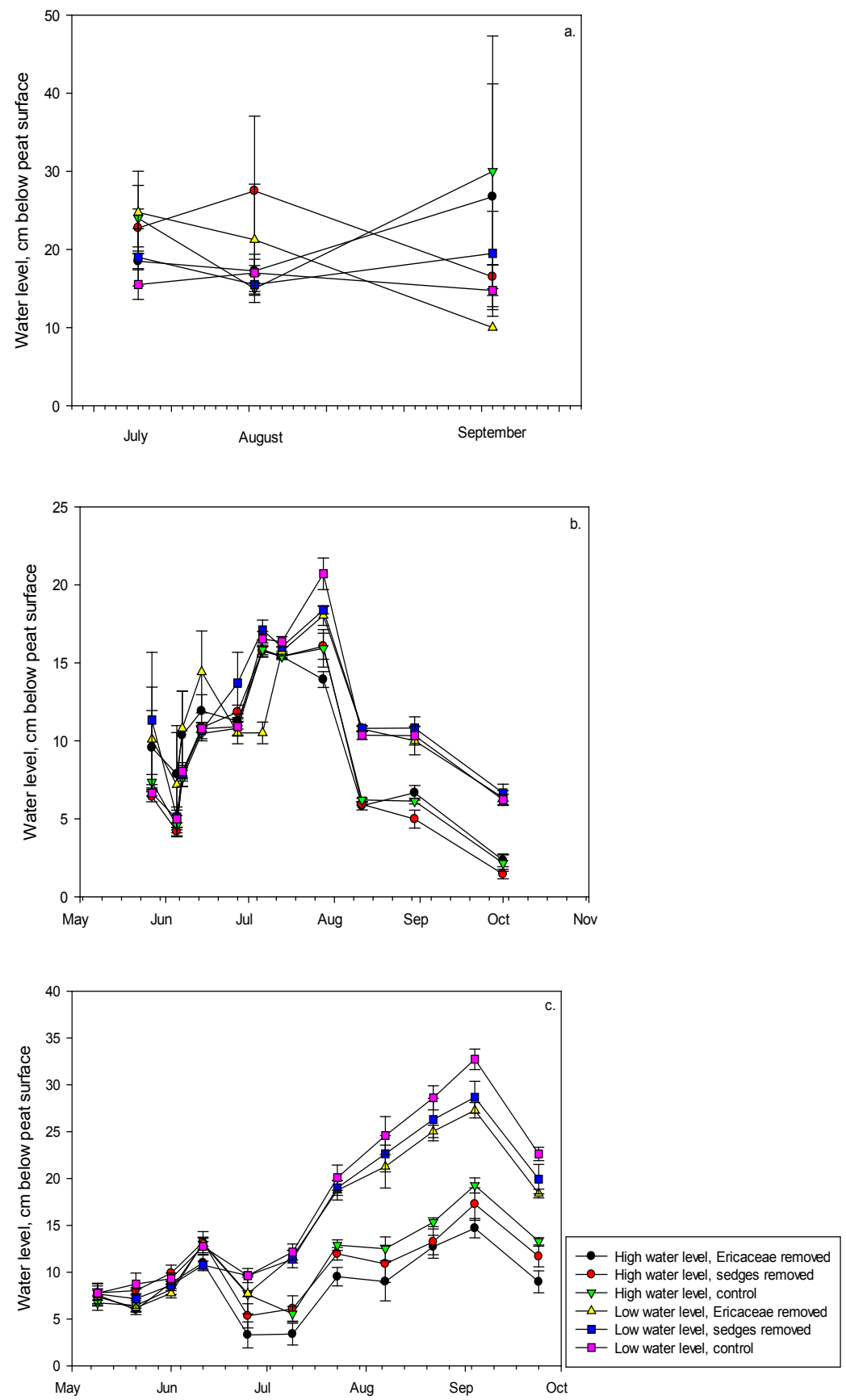

Figure 1. Water levels and treatment combinations in 2010 (a.), 2011(b.) and 2012 (c.). 


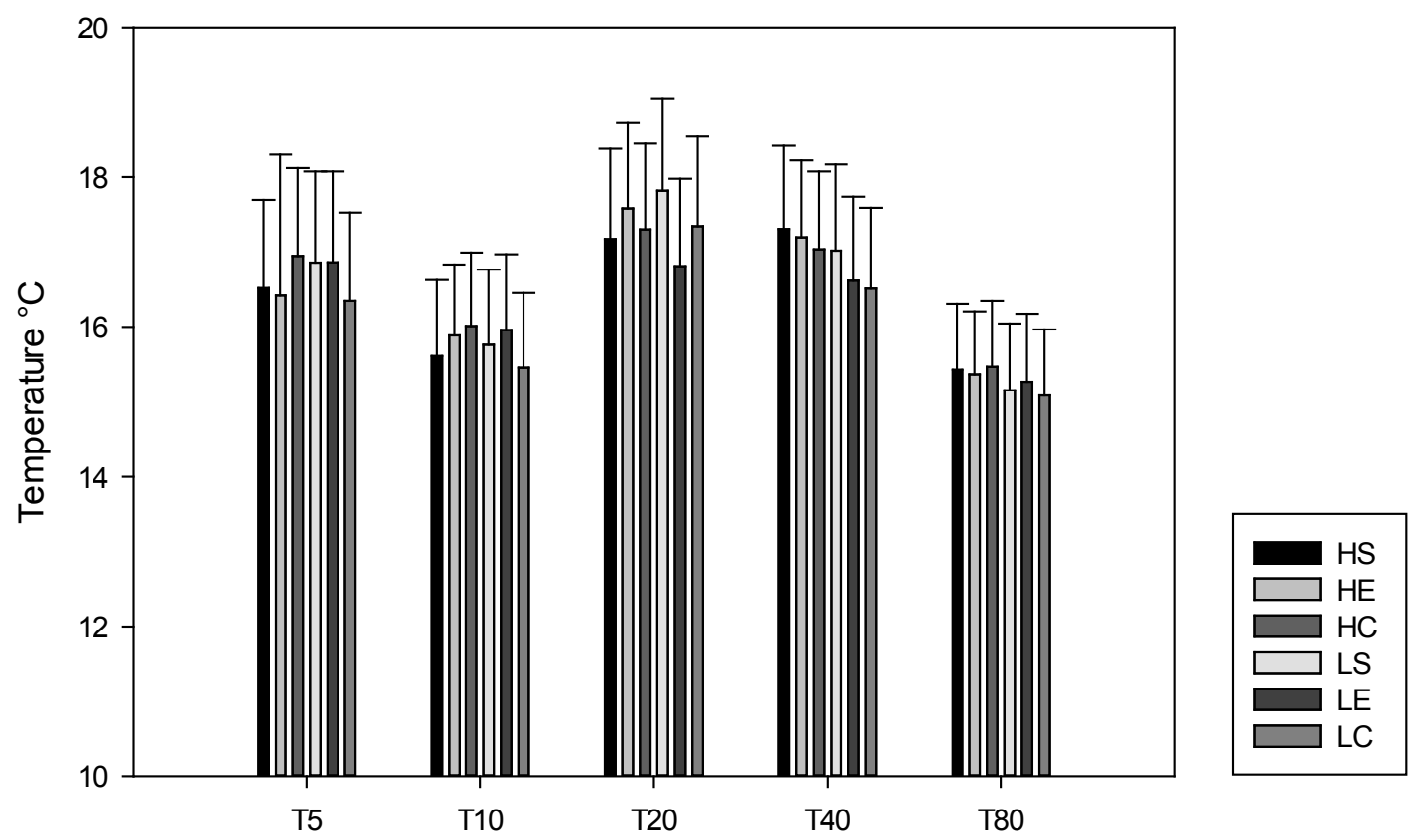

Figure 2. Peat temperatures of different treatments in different depths $(5-80 \mathrm{~cm}$ below surface). $\mathrm{H}=$ high water level, $\mathrm{L}=$ low water level, $\mathrm{S}=$ Ericaceae removed, $\mathrm{E}=$ sedges removed, $\mathrm{C}=$ control plots. Mean values based on the days samplings were performed in 2012. 

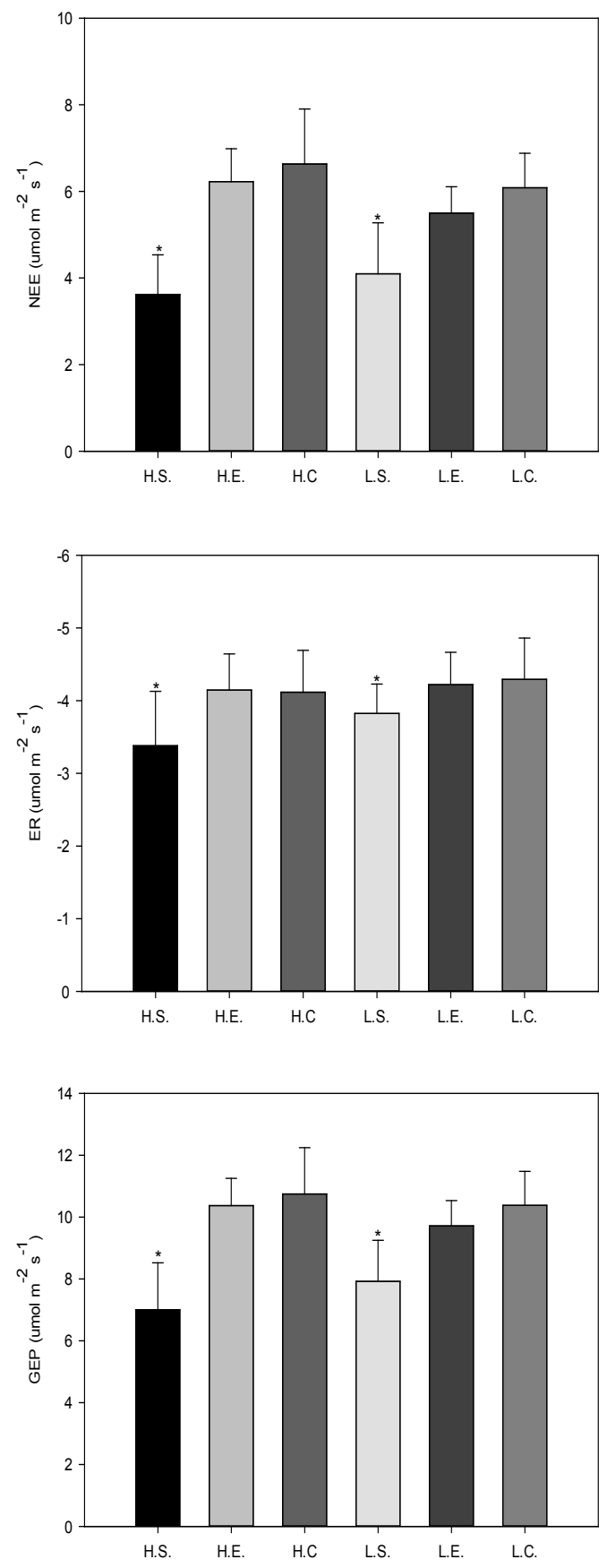

Figure 3. Different treatments and their mean NEE, ER and GEP rates in 2012. H refers to high water level and L to low water level. S is where Ericaceae have been removed, E where sedges were removed and $\mathrm{C}$ stands for control plots. * denotes sedge treatment is significantly different from Ericaceae and control vegetation treatments. 

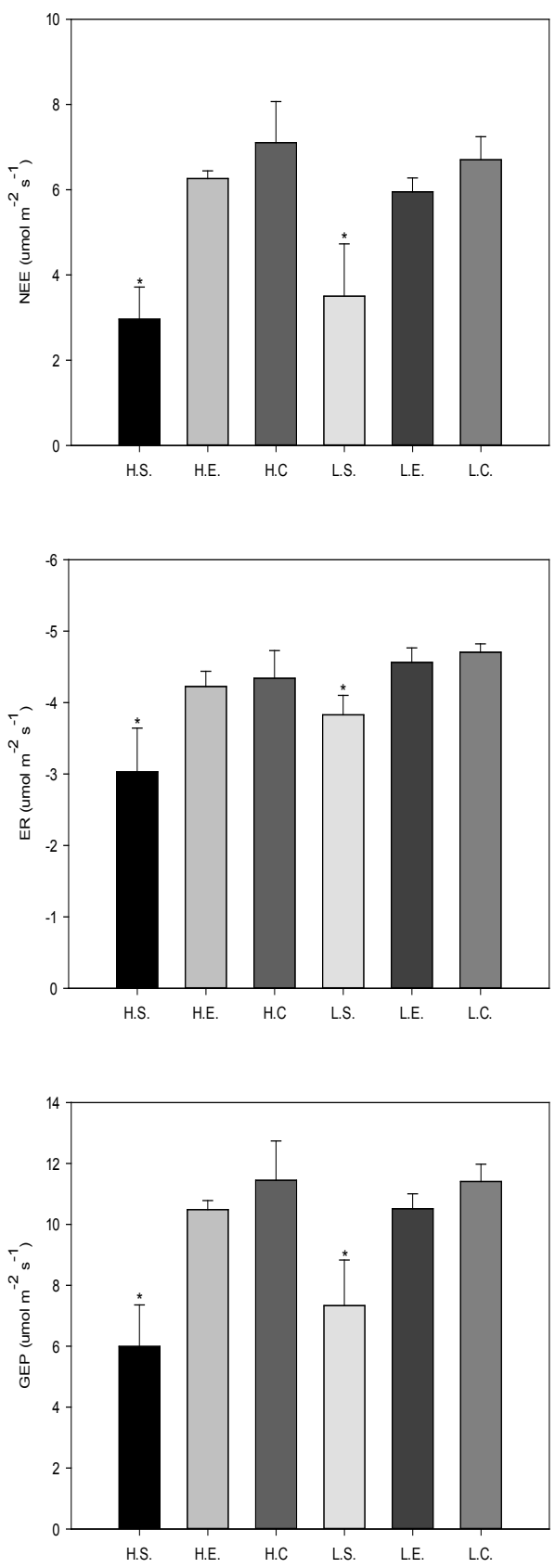

Figure 4. Different treatments and their NEE, ER and GEP rates means of 2012 July, August and September. H refers to high water level and L to low water level. S is where Ericaceae have been removed, E where sedges were removed and $\mathrm{C}$ stands for control plots. * denotes sedge treatment is significantly different from Ericaceae and control vegetation treatments. 

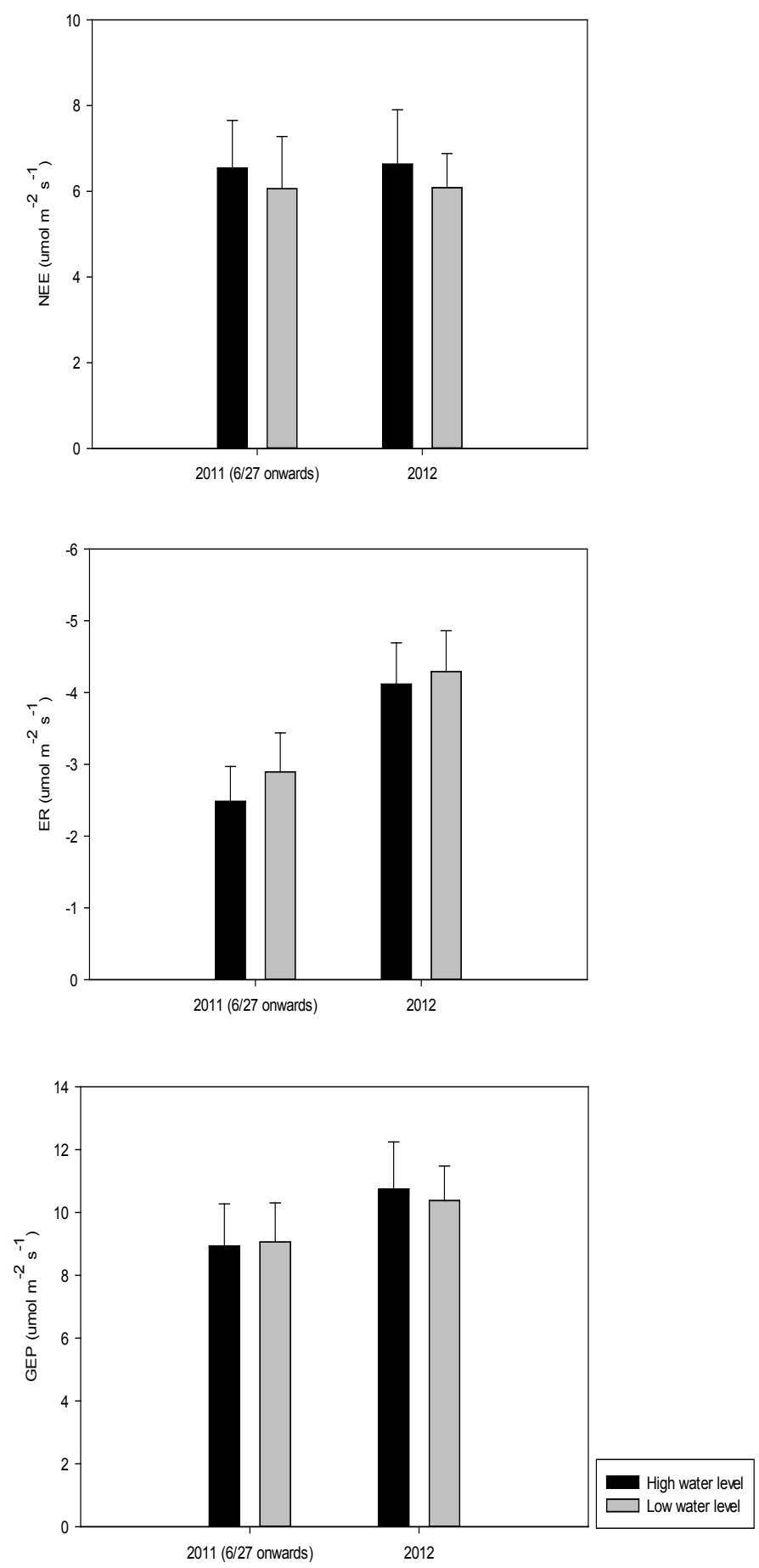

Figure 5. The mean NEE, ER and GEP of the control plots in 2011 after starting the treatments and 2012. 

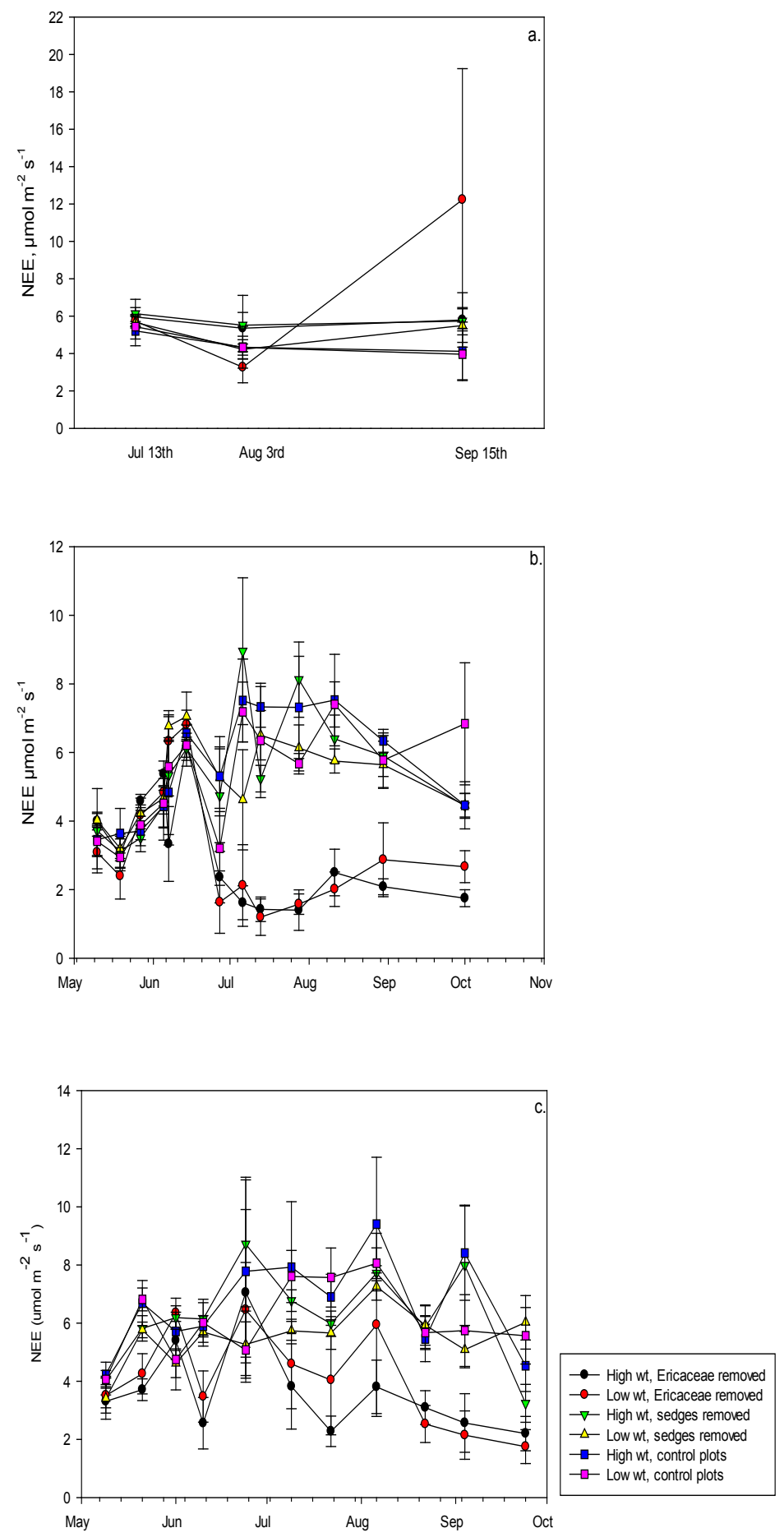

Figure 6. NEE of different water level and vegetation treatment combinations on sampling days of 2010 (a.), 2011 (b.) and 2012 (c.). 

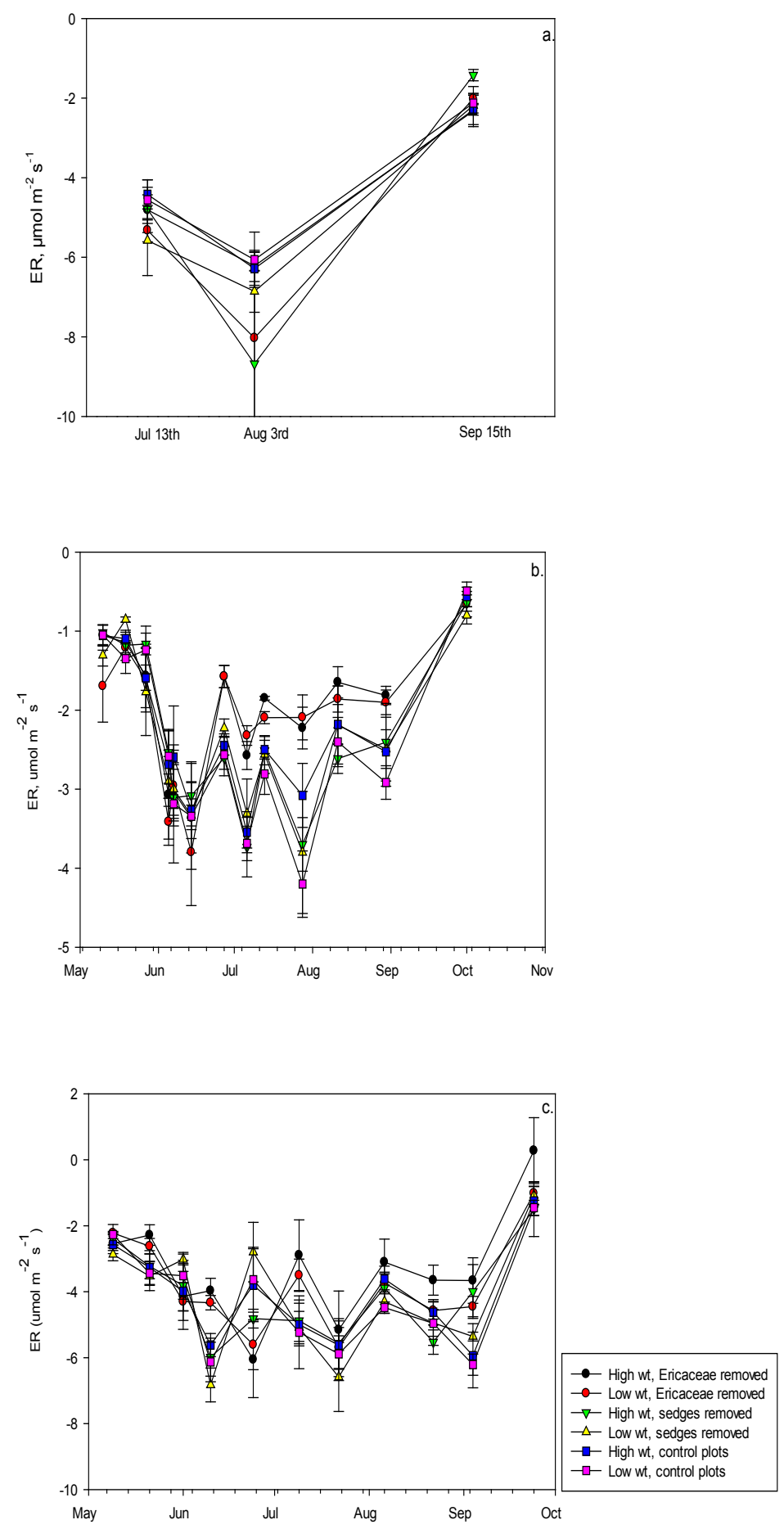

Figure 7. ER of different water level and vegetation treatment combinations on sampling days of 2010 (a.), 2011 (b.) and 2012 (c.). 



Figure 8. GEP of different water level and vegetation treatment combinations on sampling days of 2010 (a.), 2011 (b.) and 2012 (c.). 


\section{References}

Andersen R, Rochefort L, Poulin M 2010. Peat, water and plant tissue chemistry monitoring: A seven-year case-study in a restored peatland. Wetlands 30(1):159-170.

Bellisario LM, Moore TR, Bubier JL 1998. Net ecosystem $\mathrm{CO}_{2}$ exchange in a boreal peatland, northern manitoba. Ecoscience 5(4):534-541.

Brown DA 1998. Gas production from an ombrotrophic bog - effect of climate change on microbial ecology. Climatic Change 40(2):277-284.

Bubier JL, Crill P, Mosedale A, Frolking S, Linder E 2003. Peatland responses to varying interannual moisture conditions as measured by automatic $\mathrm{CO}_{2}$ chambers. Global Biogeochemical Cycles 17(2).

Bubier JL 1995. The relationship of vegetation to methane emission and hydrochemical gradients in northern peatlands. Journal of Ecology 83(3):403-420.

Carroll P and Crill P 1997. Carbon balance of a temperate poor fen. Global Biogeochemical Cycles 11(3):349-356.

Chimner RA, Cooper DJ 2003. Influence of water table levels on $\mathrm{CO}_{2}$ emissions in a colorado subalpine fen: An in situ microcosm study. Soil Biology \& Biochemistry 35(3):345-351.

Chimner RA, Welker JM, Morgan J, LeCain D, Reeder J 2010. Experimental manipulations of winter snow and summer rain influence ecosystem carbon cycling in a mixed-grass prairie, Wyoming, USA. Ecohydrology 3(3):284-293.

Chivers MR, Turetsky MR, Waddington JM, Harden JW, McGuire AD 2009. Effects of experimental water table and temperature manipulations on ecosystem $\mathrm{CO}_{2}$ fluxes in an alaskan rich fen. Ecosystems 12(8):1329-1342. 
Clymo RS 1970. The growth of "sphagnum": Methods of measurement. Journal of Ecology 58(1):13-49.

Davidson EA 2002. Minimizing artifacts and biases in chamber-based measurements of soil respiration. Agricultural \& Forest Meteorology 113(1-4):21-37.

Davidson EA and Janssens IA 2006. Temperature sensitivity of soil carbon decomposition and feedbacks to climate change. Nature 440(7081):165-173.

Dorrepaal E, Toet S, van Logtestijn RSP, Swart E, van de Weg MU, Callaghan TV, Aerts R 2009. Carbon respiration from subsurface peat accelerated by climate warming in the subarctic. Nature 460(7255):616-619.

Douma JC, van Wijk MT, Lang SI, Shaver GR 2007. The contribution of mosses to the carbon and water exchange of arctic ecosystems: Quantification and relationships with system properties. Plant, Cell and Environment 30(10):1205-1215.

Flanagan LB and Syed KH 2011. Stimulation of both photosynthesis and respiration in response to warmer and drier conditions in a boreal peatland ecosystem. Global Change Biology 17(7):2271-2287.

Frolking S, Talbot J, Jones MC, Treat CC, Kauffman JB, Tuittila E-S, Roulet N2011. Peatlands in the earth's 21st century climate system. Environmental Reviews 19:371396.

Gorham E 1991. Northern peatlands: Role in the carbon cycle and probable responses to climatic warming. Ecological Applications 1(2):182-195.

Goulden ML and Crill PM 1997. Automated measurements of $\mathrm{CO}_{2}$ exchange at the moss surface of a black spruce forest. Tree Physiology 17(8):537-542. 
Hinzman L, Bettez ND, Bolton, WR, Chapin FS, Dyurgenov MB, et al 2005. Evidence and implications of recent climate change in northern alaska and other arctic regions. Climatic Change 72(3):251-298.

Komulainen V-M, Tuittila E-S, Vasander H, Laine J 1999. Restoration of drained peatlands in southern finland: Initial effects on vegetation change and $\mathrm{CO}_{2}$ balance. Journal of Applied Ecology 36(5):634-648.

Kujala K, Seppälä M, Holappa T 2008. Physical properties of peat and palsa formation. Cold Regions Science and Technology 52(3):408-414.

Laiho R 2006. Decomposition in peatlands: Reconciling seemingly contrasting results on the impacts of lowered water levels. Soil Biology \& Biochemistry 38(8):2011-2024.

Laine J, Minkkinen K, Laiho R, Tuittila E-, Vasander H. 2000. Suokasvit - turpeen tekijät (mire vegetation and peat formation). Vammala: Department of Forest Ecology, University of Helsinki.

Lambers H, Chapin III FS, Pons TL. 2008. Plant physiological ecology. 2nd edition ed. New York, NY: Springer. 604 p.

Largent DL, Sugihara N, Wishner C 1980. Occurrence of mycorrhizae on ericaceous and pyrolaceous plants in northern california. Canadian Journal of Botany (Revue Canadienne De Botanique) 58(21):2274-2279.

Larmola T, Tuittila E-S, Tiirola M, Nykänen H, Martikainen PJ, Yrjälä K, Tuomivirta T, Fritze H 2010. The role of sphagnum mosses in the methane cycling of a boreal mire. Ecology 91(8):2356-2365.

Le Mer J and Roger P 2001. Production, Oxidation, emission and consumption of methane by soils: A review. European Journal of Soil Biology 37(2001): 25-50. 
Lemke P, Ren J, Alley RB, Allison I, Carrasco J, Flato G, Fujii Y, Kaser G, Mote P, Thomas RH, et al. 2007. Observations: Changes in snow, ice and frozen ground. In: Climate change 2007: The physical science basis. contribution of working group I to the Fourth assessment report of the intergovernmental panel on climate change. Solomon S, Qin D, Manning M, et al, editors. Cambridge, United Kingdom and New York, NY, USA.: Cambridge University Press. 337 p.

Miller RM, Smith CI, Jastrow JD, Bever JD1999. Mycorrhizal status of the genus carex (cyperaceae). American Journal of Botany 86(4):547-553.

Minkkinen K, Korhonen R, Savolainen I, Laine J 2002. Carbon balance and radiative forcing of finnish peatlands 1900-2100 - the impact of forestry drainage. Global Change Biology 8(8): 785-799.

Moore TR and Knowles R. 1989. The influence of water table levels on methane and carbon dioxide emissions from peatland soils. Canadian Journal of Soil Science 69(1):33-38.

Moore TR, Roulet NT, Waddington JM 1998. Uncertainty in predicting the effect of climatic change on the carbon cycling of canadian peatlands. Climatic Change 40(2):229-245.

Oksanen PO and Väliranta M 2006. Palsasuot muuttuvassa ilmastossa. Palsa mires in a changing climate. Suo 57(2):33-43.

Raghoebarsing AA, Smolders AJP, Schmid MC, Rijpstra IC, Wolters-Arts M, et al 2005. Methanotrophic symbionts provide carbon for photosynthesis in peat bogs. Nature 436(7054):1153-1156.

Read DJ, Leake JR, Perez-Moreno J 2004. Mycorrhizal fungi as drivers of ecosystem processes in heathland and boreal forest biomes. Canadian Journal of Botany/Revue Canadienne De Botanique 82(8):1243-1263. 
Roulet NT, Ash R, Moore TR 1992. Low boreal wetlands as a source of atmospheric methane. Journal of Geophysical Research-Atmospheres 97:3739-3749.

Rydin H and Jeglum J. 2006. The biology of peatlands. 1st ed. New York: Oxford University Press.

Shannon RD and White JR 1994. A three-year study of controls on methane emissions from two Michigan peatlands. Biogeochemistry 27(1):35-60.

Shaver GR, Billings WD, Chapin FS III, Giblin AE, Nadelhoffer KJ, Oecher WC, Rastetter EB 1992. Global change and the carbon balance of arctic ecosystems. Bioscience 42(6):433-441.

Silvola J, Alm J, Ahlholm U, Nykänen H, Martikainen PJ 1996. CO 2 fluxes from peat in boreal mires under varying temperature and moisture conditions. Journal of Ecology 84(2):219.

Strack M, Waller MF, Waddington JM 2006. Sedge succession and peatland methane dynamics: A potential feedback to climate change. Ecosystems 9(2):278-287.

Treat CC, Bubier JL, Varner RK, Crill PM 2007. Timescale dependence of environmental and plant-mediated controls of $\mathrm{CH}_{4}$ flux in a temperate fen. Journal of Geophysical Research G: Biogeosciences 112(1).

Trenberth KE, Jones PD, Ambenje P, Bojariu R, Easterling D, Klein Tank A, Parker D, Rahimzadeh F, Renwick JA, Rusticucci M, et al. 2007. Observations: Changes in snow, ice and frozen ground. In: Climate change 2007: The physical science basis. contribution of working group I to the Fourth assessment report of the intergovernmental panel on climate change. Solomon S, Qin D, Manning M, et al., editors. Cambridge, United Kingdom and New York, NY, USA.: Cambridge University Press. 337 p. 
Turetsky MR, Wieder RK, Vitt DH 2002. Boreal peatland C fluxes under varying permafrost regimes. Soil Biology \& Biochemistry 34(7):907-912.

Updegraff K, Pastor J, Bridgham SD, Johnston CA 1995. Environmental and substrate controls over carbon and nitrogen mineralization in northern wetlands. Ecological Applications 5(1):151-163.

Van Breemen, N 1995. How Sphagnum bogs down other plants. Tree 10(7):270-275.

Vourlitis GL, Oechel WC, Hastings SJ, Jenkins MA 1993. A system for measuring in situ $\mathrm{CO}_{2}$ and $\mathrm{CH}_{4}$ flux in unmanaged ecosystems: An arctic example. Functional Ecology $7(3): 369-379$.

Waddington JM, Roulet NT, Swanson RV 1996. Water table control of $\mathrm{CH}_{4}$ emission enhancement by vascular plants in boreal peatlands. Journal of Geophysical Research-Biogeosciences 101(D17):22775-22785.

Weltzin JF, Pastor J, Harth C, Bridgham SD, Updegraff K, Chapin CT 2000. Response of bog and fen plant communities to warming and water-table manipulations. Ecology 81(12):3464-3478.

Whalen SC 2005. Biogeochemistry of methane exchange between natural wetlands and the atmosphere. Environmental Engineering Science 22(1):73-94.

Wofsy SC, Goulden ML, Munger JW, Fan S-M, Bakwin PS, Daube BC, Bassow SL, Bazzaz FA1993. Net exchange of $\mathrm{CO}_{2}$ in a mid-latitude forest. Science 26(5112):1314-1317.

Wuebbles DJ and Hayhoe K 2002. Atmospheric methane and global change. EarthScience Reviews 57(3-4):177-210. 